\title{
Structure and Nature of the Active Sites in CoMo Hydrotreating Catalysts. An EXAFS Study of the Reaction with Selenophene
}

\author{
Bob R. G. Leliveld,* Jos A. J. van Dillen, John W. Geus, and Diek C. Koningsberger \\ Department of Inorganic Chemistry, Debye Institute, University of Utrecht, P.O. Box 80083, \\ 3508 TB Utrecht, The Netherlands
}

\author{
Mark de Boer \\ Akzo Nobel Catalysts, P.O. Box 247, 3800 AE Amersfoort, The Netherlands
}

Received: July 23, 1997; In Final Form: October 6, $1997^{\circledR}$

\begin{abstract}
The genesis of sulfur vacancies on sulfided $(\mathrm{Co}) \mathrm{Mo} / \mathrm{Al}_{2} \mathrm{O}_{3}$ catalysts was studied with EXAFS at the reaction temperature $(673 \mathrm{~K})$ in a $\mathrm{H}_{2}$ and $\mathrm{H}_{2} /$ thiophene gas atmosphere. For Mo no significant changes in the sulfur coordination were observed for either the Co-promoted or the unpromoted sample. The experiments indicated that in Co-promoted $\mathrm{Mo} / \mathrm{Al}_{2} \mathrm{O}_{3}$ vacancies are primarily formed on the Co atom. The sulfur coordination of the cobalt changed from 6.0 to 5.2 upon reduction with $\mathrm{H}_{2}$, followed by a slight increase to 5.4 by treatment with $\mathrm{H}_{2} /$ thiophene. The reaction of selenophene (a structural analogue of thiophene) in hydrogen with sulfided (Co) $\mathrm{Mo} / \mathrm{Al}_{2} \mathrm{O}_{3}$ catalysts was also investigated with EXAFS. It was possible to monitor the incorporation of $\mathrm{Se}$ in the metal sulfide phase. Characterization of the promoted catalyst after HD-Se at $473 \mathrm{~K}$ showed that Se was exclusively coordinated to the Co atoms. In contrast, data obtained after HD-Se at $673 \mathrm{~K}$ revealed that the Se atoms were located in the position of the bridging sulfur atoms between Co and Mo. Accordingly, a structural model is proposed that involves two types of active sites for hydrodesulfurization on the sulfided Co-promoted Mo catalyst. The first type consists of a sulfur vacancy that is only associated with the promoter atoms, which is created at low temperatures. At higher temperatures, a second type of site is produced by removal of sulfur atoms that are bonded to both Co and Mo atoms.
\end{abstract}

\section{Introduction}

Supported metal sulfide catalysts are extensively used in the hydrotreatment of petroleum feedstocks. In the modern refinery, hydrotreating involves flexible process conditions that depend on the combination of the crude to be processed and desired product selectivity. Mo catalysts are usually promoted with Co or Ni to improve the activity. During the last 50 years and especially since the early 1970's, an enormous number of papers have been published on the preparation and structure of these catalysts, the reaction mechanisms of HDS (hydrodesulfurization) and HDN (hydrodenitrogenation), the nature of the active sites, and the origin of the promotional effect of $\mathrm{Co}$ and $\mathrm{Ni}$. For details on these subjects the reader is referred to some extensive reviews. ${ }^{1-16}$

For decades, the structure of the promoted catalysts has been an issue of debate. Schuit and Gates ${ }^{17}$ proposed a monolayer model. The (pseudo)intercalation model was brought forward by Voorhoeve and Stuiver $^{18}$ and Farragher and Cossee. ${ }^{19}$ Simultaneously, Delmon et al. ${ }^{20}$ proposed the contact synergy or remote control model, in which they assumed an intimate contact between $\mathrm{MoS}_{2}$ and $\mathrm{Co}_{9} \mathrm{~S}_{8}$. Nowadays, the generally accepted model is that the active phase consists of small $\mathrm{MoS}_{2}$ platelets with $\mathrm{Co}$ or $\mathrm{Ni}$ atoms decorating the edges. Topsøe et al. ${ }^{7}$ introduced this so-called $\mathrm{Co}-\mathrm{Mo}-\mathrm{S}$ model based on Mössbauer and EXAFS results. Crajé et al. ${ }^{21,22}$ and Bouwens et al. $^{23-25}$ further refined the structural model. Bouwens revealed with EXAFS a Co-Mo interaction with a bond length of $2.80 \AA$ and described in detail the position of Co promotor atoms on the edges of $\mathrm{MoS}_{2}$ slabs.

* To whom correspondence should be addressed. Tel.: +31 302536762 . Fax: +31 30 2511027. E-mail: leliveld@chem.ruu.nl.

${ }^{\otimes}$ Abstract published in Advance ACS Abstracts, December 1, 1997.
The above models give a detailed description of the structure of the promoted Mo catalyst, but the exact structure and nature of the active sites for hydrode sulfurization in both unpromoted and promoted HDS catalysts have still not been elucidated. There is ample evidence that formation of coordinative unsaturated sites (CUS sites) (e.g., sulfur vacancies) plays an important role in the HDS mechanism. These CUS sites were shown to be located on the edges and corners of $\mathrm{MoS}_{2}$ slabs whether decorated with promoter atoms (see, for example, Topsøe et al. ${ }^{16}$ and references therein). A precise description of the structural position of the sulfur vacancies and of their immediate surrounding is still lacking. ${ }^{15}$

To achieve a more precise description of the active sites, the investigation with EXAFS of the adsorption of selenophene (a structural analogue of thiophene) on a HDS catalyst by Startsev et al. ${ }^{26}$ was very promising. EXAFS can distinguish Se of the reactant from the structural $\mathrm{S}$ atoms, which allows one to study the behavior of the heteroatom of the reactant within the metal sulfide. In a very tentative analysis of the $\mathrm{Ni}-\mathrm{K}$ edge, Startsev et al. claimed that selenophene was only coordinated to the $\mathrm{Ni}$ atoms in their $\mathrm{NiMo} / \mathrm{Al}_{2} \mathrm{O}_{3}$ catalyst. This strongly suggests that the active site has to be associated with the promoter atoms. Ledoux et al. ${ }^{27}$ showed with ${ }^{59} \mathrm{Co}$ NMR that indeed Co-Mo-S and $\mathrm{Co}-\mathrm{Mo}-\mathrm{Se}$ have the same structure, which justifies the use of $\mathrm{Se}$ as a substitute for $\mathrm{S}$. However, Medici et al. ${ }^{28}$ questioned the EXAFS results of Startsev, since they observed no difference between the spectra of the $\mathrm{Ni}-\mathrm{K}$ edge of sulfided $\mathrm{Ni}-\mathrm{Mo} / \mathrm{Al}_{2} \mathrm{O}_{3}$ before and after adsorption of selenophene at room temperature.

The objective of our research was to study the genesis and location of sulfur vacancies (active sites) on both unpromoted and Co-promoted $\mathrm{Mo} / \mathrm{Al}_{2} \mathrm{O}_{3}$ catalysts. First, we carried out in situ reduction experiments with $\mathrm{H}_{2}$ at $673 \mathrm{~K}$ of sulfided samples 
since recent EXAFS results of Topsøe et al. ${ }^{29}$ indicated that the sulfur coordination of $\mathrm{Co}$ in the $\mathrm{Co}-\mathrm{Mo}-\mathrm{S}$ structure changes upon reduction with $\mathrm{H}_{2}$. We extended their study by exploring the sulfur coordination of both Co and Mo and the influence of subsequent exposition to thiophene. Further, we studied HD-Se of selenophene over the sulfided catalysts between 473 and $673 \mathrm{~K}$. In this way, selenophene was hydrogenated and Se was incorporated in the $\mathrm{Co}-\mathrm{Mo}-\mathrm{S}$ structure. Next to the usual characterization by EXAFS of the Co and Mo edge, also the Se edge was studied. The analysis of the data of all three edges enabled us to describe in detail the absorbing (active) site from the position of both the reactant and the catalyst and to keep track of the location of Se in the metal sulfide phase. The results indicate that at $473 \mathrm{~K}$ selenophene adsorbs on the Co sites, which can therefore "formally" be designated as the active sites. At $673 \mathrm{~K}$ incorporation of Se is observed in a bridging position between $\mathrm{Co}$ and Mo on the $\mathrm{MoS}_{2}$ edges at $673 \mathrm{~K}$. In a following paper, ${ }^{30}$ we will use the structural results obtained with EXAFS to establish a structure-activity relation of sulfided $(\mathrm{Co}) \mathrm{Mo} / \gamma$ alumina catalysts in the hydrodesulfurization reaction of thiophene.

\section{Experimental Section}

Preparation of the Catalysts. A 15 wt $\% \mathrm{MoO}_{3} / \gamma-\mathrm{Al}_{2} \mathrm{O}_{3}$ (denoted $\mathrm{Mo} / \mathrm{Al}_{2} \mathrm{O}_{3}$ ) catalyst was prepared by incipient wetness impregnation of preshaped bodies of $\gamma-\mathrm{Al}_{2} \mathrm{O}_{3}(150-425 \mu \mathrm{m}$, Ketjen CK-300, specific surface area $200 \mathrm{~m}^{2} / \mathrm{g}$, pore volume $0.63 \mathrm{~mL} / \mathrm{g})$ with an aqueous solution of $\left(\mathrm{NH}_{4}\right)_{6} \mathrm{Mo}_{7} \mathrm{O}_{24} \cdot 6 \mathrm{H}_{2} \mathrm{O}$ (Merck, p.a.) containing 25\% ammonia. A $\gamma$-alumina supported sample containing 3.8 wt $\% \mathrm{Co}_{3} \mathrm{O}_{4}$ and 14 wt $\% \mathrm{MoO}_{3}$ (denoted $\mathrm{CoMo} / \mathrm{Al}_{2} \mathrm{O}_{3}$ ) was prepared by incipient wetness coimpregnation of $\gamma-\mathrm{Al}_{2} \mathrm{O}_{3}$ (Ketjen CK-300) with an aqueous solution containing the required amounts of $\left(\mathrm{NH}_{4}\right)_{6} \mathrm{Mo}_{7} \mathrm{O}_{24} \cdot 6 \mathrm{H}_{2} \mathrm{O}$ and $\mathrm{Co}\left(\mathrm{NO}_{3}\right)_{2}$. $6 \mathrm{H}_{2} \mathrm{O}$. All catalysts were subsequently dried in an air flow for $4 \mathrm{~h}$ at $298 \mathrm{~K}$, in static air at $383 \mathrm{~K}$ for $16 \mathrm{~h}$, and calcined in air at $723 \mathrm{~K}$ during $16 \mathrm{~h}$. A commercial $\mathrm{CoMo} / \mathrm{Al}_{2} \mathrm{O}_{3}$ hydrodesulfurization catalyst (KF752, denoted com-CoMo/ $\mathrm{Al}_{2} \mathrm{O}_{3}$ ) was obtained from Akzo Nobel Chemicals B.V. and used without further treatment.

Catalytic Activity and Temperature-Programmed Desorption. Temperature-programmed desorption (TPD) and catalytic activity experiments were performed with an automated microflow apparatus. One $\mathrm{mL}$ of catalyst was put on a quartz filter in a quartz lab reactor $(8 \mathrm{~mm} \varnothing)$. Prior to reaction, the catalyst was sulfided in a $100 \mathrm{~mL} / \mathrm{min}$ flow of $\mathrm{H}_{2} \mathrm{~S} / \mathrm{H}_{2} / \mathrm{Ar}(10$ / 40/50), while the temperature was linearly raised from 298 to $673 \mathrm{~K}(5 \mathrm{~K} / \mathrm{min})$. After $30 \mathrm{~min}$ at $673 \mathrm{~K}$ the flow was switched to $50 \mathrm{~mL} / \mathrm{min}$ of a mixture of either 2 vol \% selenophene (Aldrich, 99\%) in or $2.4 \mathrm{vol} \%$ thiophene in $\mathrm{H}_{2}$. The reactor effluent was analyzed with a gas chromatograph using a Chrompack CP-sil-5 CB column and a FID. The catalytic activity, expressed as conversion of the reactant, was measured at temperatures between 673 and $423 \mathrm{~K}$ at atmospheric pressure.

After the sample was cooled to room temperature in selenophene $/ \mathrm{H}_{2}$, the flow was switched to $100 \mathrm{~mL} / \mathrm{min} \mathrm{Ar}$ and a temperature-programmed desorption profile was recorded (298$523 \mathrm{~K}, 5 \mathrm{~K} / \mathrm{min})$. The selenophene concentration after the reactor was monitored with a UV/vis spectrophotometer (Varian, Quartz cuvettes Hellma, $20 \mathrm{~mm}$ ). The selenophene absorption was detected at $\lambda=245 \mathrm{~nm}$.

EXAFS Data Collection. The EXAFS measurements were performed at EXAFS station 9.2 and 8.1 of the Wiggler beam line of the SRS at Daresbury (U.K.). The Si[220] double-crystal monochromator was detuned to $50 \%$ intensity to diminish the presence of higher harmonics. The measurements were carried out in transmission mode using optimized ion chambers as detectors. To minimize high- and low-frequency noise, the counting time per data point varied from $1 \mathrm{~s}$ at $k=3 \AA^{-1}$ to 3 $\mathrm{s}$ at $k=20 \AA^{-1}$, and at least three scans were recorded and averaged. The energy calibration was performed by means of metal foils placed in series with the sample using a third ionization chamber.

A small number of samples were measured at BL18 (BM29) at the ESRF in Grenoble. A double-crystal Si[311] monochromator was used, and photodiodes were employed as detectors. Double-multilayer (W/Si) mirrors were used to minimize the presence of higher harmonics, which reduced the beam intensity to approximately $60 \%$. The counting time per data point was 2 s over the whole $k$-range, and at least three scans were recorded and averaged.

The catalyst samples were pressed into self-supporting wafers and mounted in an in situ EXAFS cell. ${ }^{31}$ The thickness of the wafer was thus chosen to give an absorbance $(\mu \mathrm{x})$ of 2.5 for an optimal signal-to-noise ratio. To prevent self-absorption at the Mo-edge with the highly loaded $\mathrm{Mo} / \mathrm{Al}_{2} \mathrm{O}_{3}$ and $\mathrm{CoMo} / \mathrm{Al}_{2} \mathrm{O}_{3}$ samples, the wafer thickness was chosen to obtain a step in absorbance of 1.0 in the edge region.

Reduction by $\mathrm{H}_{2}$ and the Adsorption of Selenophene. Prior to all experiments, the catalysts were sulfided in a $10 \%$ $\mathrm{H}_{2} \mathrm{~S} / \mathrm{H}_{2}$ flow of $50 \mathrm{~mL} / \mathrm{min}^{-1}$ at $673 \mathrm{~K}$ for $30 \mathrm{~min}(5 \mathrm{~K} / \mathrm{min}$ $298-673 \mathrm{~K})$. After the sample was cooled to $298 \mathrm{~K}$ in $\mathrm{H}_{2} \mathrm{~S} /$ $\mathrm{H}_{2}$, EXAFS spectra of the $\mathrm{Mo} / \mathrm{Al}$ and $\mathrm{CoMo} / \mathrm{Al}$ catalyst were recorded at both the $\mathrm{Mo}(20 \mathrm{keV})$ and Co edge $(7709 \mathrm{eV})$ at 77 and $673 \mathrm{~K}$. Subsequently, a flow of $50 \mathrm{~mL} / \mathrm{min}_{2}$ was passed through the cell, and EXAFS spectra of the "reduced" samples were recorded at $673 \mathrm{~K}$ for both edges. Additionally, thiophene (2.4 vol \%) was added to the $\mathrm{H}_{2}$ stream and spectra were again measured at $673 \mathrm{~K}$.

In the HD-Se experiments $\mathrm{Mo} / \mathrm{Al}, \mathrm{CoMo} / \mathrm{Al}$, and com-CoMo/ $\mathrm{Al}$ were exposed to a mixture of selenophene in $\mathrm{H}_{2}$ (saturation temperature $273 \mathrm{~K}$, approximately 2 vol \%) at $673 \mathrm{~K}$ for $1 \mathrm{~h}$. Subsequently, the samples were allowed to cool to $423 \mathrm{~K}$, and the flow was switched to $\mathrm{He}(100 \mathrm{~mL} / \mathrm{min})$. After $30 \mathrm{~min}$, the samples were cooled to $298 \mathrm{~K}$ and the cells were closed. EXAFS spectra were recorded at the Co, Mo, and Se edge $(12658 \mathrm{eV})$ at $77 \mathrm{~K}$.

In a separate experiment, the com-CoMo/Al catalyst was exposed to the mixture of selenophene in $\mathrm{H}_{2}$ at $473 \mathrm{~K}$ for a period of $8,16,32$, and $64 \mathrm{~min}$. After a He flush at $423 \mathrm{~K}$, spectra were recorded at the Se-edge at $77 \mathrm{~K}$. The latter experiments were measured at BL18 (BM29) of the ESRF in Grenoble.

EXAFS Data Analysis. Standard procedures were used to extract the EXAFS data from the measured absorption spectra. Normalization was done by dividing the data by the height of the absorption edge, and the background was subtracted using cubic spline routines. ${ }^{32}$ Phase shifts and backscattering amplitudes to calculate the EXAFS contributions were obtained from reference compounds ${ }^{33-37}$ and were theoretically calculated with the FEFF-3.1 code $^{38}$ (see Table 1). The input values in FEFF for $\sigma^{2}$ and $\mathrm{S}_{\mathrm{o}}^{2}$ for all references were 0 and 0.8 , respectively.

Multiple-shell fitting of the EXAFS data was done in R-space. The difference file technique was applied together with phasecorrected Fourier transforms to resolve the separate contributions. $^{39}$ In the difference file technique each absorberbackscatterer contribution $\chi_{i}$ (represented by eq 1 ) can separately be optimized.

$$
\chi_{i}=\chi_{\exp }-\sum_{k \neq i} \chi_{k}
$$

A full optimization of the fits was performed by allowing all parameters of all contributions to vary. Coordination numbers 
TABLE 1: Crystallographic Data and FEFF Input for the References

\begin{tabular}{llrrr}
\hline coordination & \multicolumn{1}{c}{ compd/FEFF } & $N$ & $R(\AA)$ & ref \\
\hline $\mathrm{Mo}-\mathrm{O}$ & $\mathrm{Na}_{2} \mathrm{MoO}_{4} \cdot 2 \mathrm{H} 2 \mathrm{O}$ & 4 & 1.77 & 32 \\
$\mathrm{Mo}-\mathrm{S}$ & $\mathrm{MoS}_{2}$ & 6 & 2.41 & 33 \\
$\mathrm{Mo}-\mathrm{Mo}$ & $\mathrm{MoS}_{2}$ & 6 & 3.16 & 33 \\
$\mathrm{Co}-\mathrm{S}$ & $\mathrm{CoS}_{2}$ & 6 & 2.32 & 34 \\
$\mathrm{Co}-\mathrm{Co}$ & $\mathrm{CoO}$ & 12 & 3.02 & 35 \\
$\mathrm{Ni}-\mathrm{Mo}$ & $\left(\left(\mathrm{C}_{6} \mathrm{H}_{5}\right)_{4} \mathrm{P}\right)_{2} \mathrm{Ni}\left(\mathrm{MoS}_{4}\right)_{2}$ & 2 & 2.80 & 36 \\
$\mathrm{Mo}-\mathrm{Se}$ & $\mathrm{FEFF}$ & 4 & 2.40 & \\
$\mathrm{Co}-\mathrm{Se}$ & $\mathrm{FEFF}$ & 4 & 2.40 & \\
$\mathrm{Se}-\mathrm{C}$ & $\mathrm{FEFF}$ & 4 & 2.40 & \\
$\mathrm{Se}-\mathrm{Co}$ & $\mathrm{FEFF}$ & 4 & 2.40 & \\
$\mathrm{Se}-\mathrm{Mo}$ & $\mathrm{FEFF}$ & 4 & 2.40 & \\
$\mathrm{Se}-\mathrm{S}$ & $\mathrm{FEFF}$ & 4 & 3.20 & \\
$\mathrm{Se}-\mathrm{Se}$ & $\mathrm{FEFF}$ & 4 & 3.20 &
\end{tabular}

were corrected for the difference in absorber-backscatterer distance between reference compound and unknown assuming an electron mean free path of $5 \AA{ }^{40}$ The XDAP data analysis software program was used. ${ }^{41}$

The reliability of the calculated fit is usually expressed as the goodness of fit $\epsilon_{v}^{2}$, which includes the statistical noise on the data. ${ }^{42}$ However, it proved that the random noise in some spectra is so low that $\epsilon_{v}{ }^{2} \gg 1$. In that case, the noise is dominated by systematic errors from the measurement and data analysis. To correct the standard deviations of the structural parameters for the systematic errors $\epsilon_{v}{ }^{2}$ should be corrected as described by Stern et al. ${ }^{43}$ The analysis program used, however, is not yet capable of performing this kind of statistical analysis. Alternatively, we have chosen to express the quality of fit as the difference between the absolute or imaginary part of the Fourier transform of the experimental data with that of the model Fourier transform. These differences are described by the $\mathrm{FT}^{n}$ variance

$$
\mathrm{FT}^{n}=100 \frac{\int\left(\mathrm{FT}_{\text {model }}^{n}(R)-\mathrm{FT}_{\text {exp }}^{n}(R)\right)^{2}}{\int\left(\mathrm{FT}_{\text {exp }}^{n}(R)\right)^{2}}
$$

in which $n$ represents the weight of the Fourier transform. The errors in the resulting fit parameters are estimated to be $5 \%$ in coordination number $N, 1 \%$ in distance $R, 10 \%$ in DebyeWaller factor $\Delta \sigma^{2}$, and $10 \%$ in $\Delta E_{\mathrm{o}}$, according to Li et al. ${ }^{44}$

\section{Results}

Reduction Experiments on $\mathrm{Mo} / \mathrm{Al}_{2} \mathrm{O}_{3}$ and $\mathrm{CoMo} / \mathrm{Al}_{2} \mathrm{O}_{3}$ Catalysts. To study the genesis of sulfur vacancies the sulfided catalysts were treated with $\mathrm{H}_{2}$ and characterized in situ at 673 K. Measuring EXAFS at this high temperature circumvents possible structural rearrangements of coordinative unsaturated sites or chemisorption of sulfur species during cooling to room temperature or liquid nitrogen temperature. Figure 1a shows the raw EXAFS data for $\mathrm{Mo} / \mathrm{Al}_{2} \mathrm{O}_{3}$ measured at $673 \mathrm{~K}$ within a $\mathrm{H}_{2} \mathrm{~S} / \mathrm{H}_{2}$ atmosphere. As can be seen in Figure 1, the data quality at $673 \mathrm{~K}$ is still very good. At high temperatures the Debye-Waller factors increase, which result in a decrease of the amplitude of the EXAFS signal. Additionally, anharmonic behavior of the interatomic thermal motion may be observed, which excludes the use of a first-order-disorder approximation in the EXAFS data analysis. Analysis of data measured at several temperatures between 673 and $77 \mathrm{~K}$ indicated a linear temperature dependence of the Debye-Waller factors and no decrease in coordination distances, which is indicative for harmonic behavior. For these reasons, all data were analyzed, assuming a harmonic behavior of the Debye-Waller factors.

The Fourier transforms for $\mathrm{Mo} / \mathrm{Al}_{2} \mathrm{O}_{3}$ exposed at $673 \mathrm{~K}$ to subsequently $\mathrm{H}_{2} \mathrm{~S} / \mathrm{H}_{2}, \mathrm{H}_{2}$, and thiophene/ $\mathrm{H}_{2}$ are displayed in
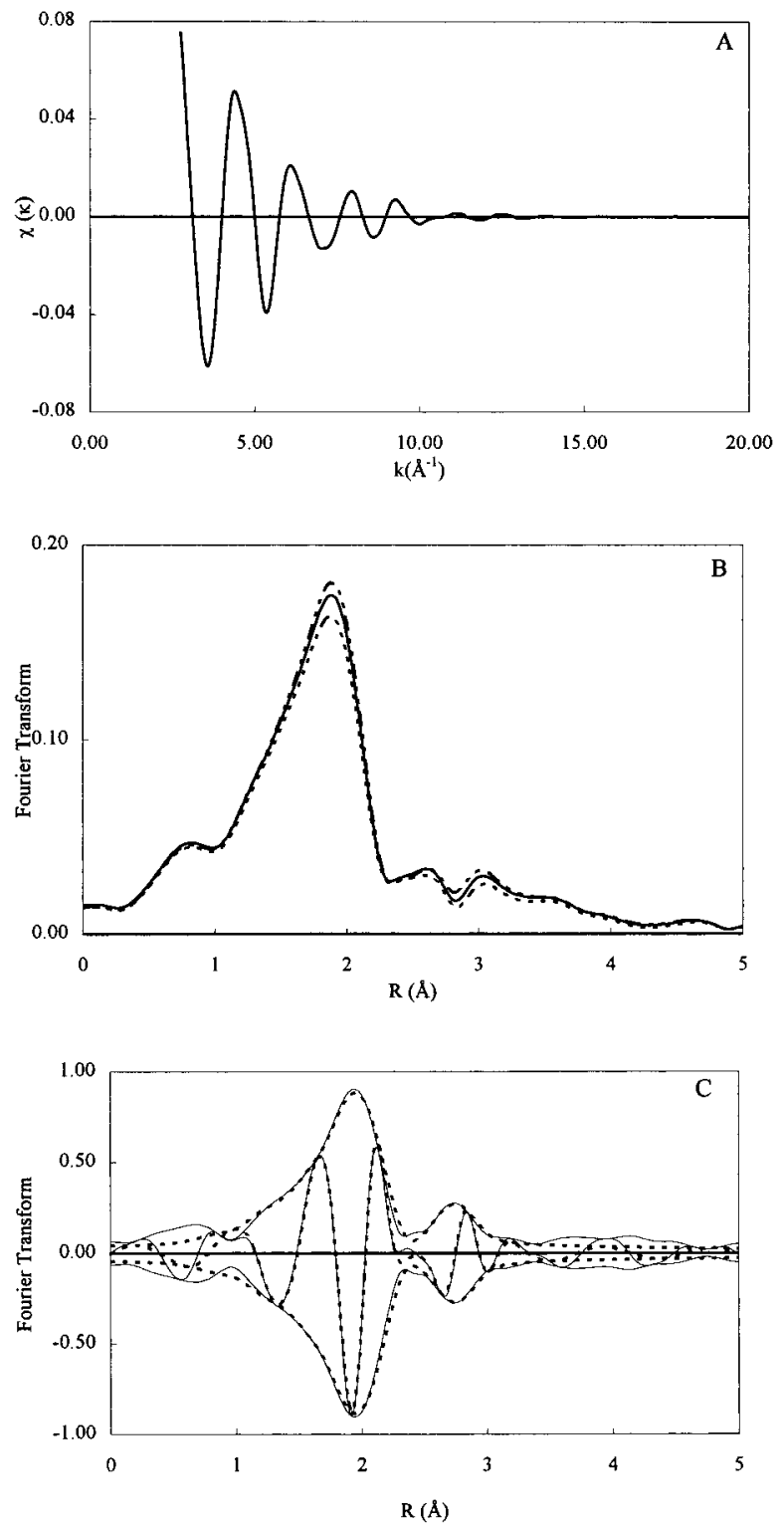

Figure 1. (A) Mo-K EXAFS spectrum (unweighted) of sulfided Mo/ $\mathrm{Al}_{2} \mathrm{O}_{3}$ measured at $673 \mathrm{~K}$. (B) Absolute part of Fourier transform $\left(k^{1}\right.$, $\Delta k=3.1-14.0 \AA^{-1}$ ) of sulfided $\mathrm{Mo}_{\mathrm{Al}} \mathrm{Al}_{2} \mathrm{O}_{3}$ (solid line) after reduction with $\mathrm{H}_{2}$ (dotted line), and after exposition to thiophene/ $\mathrm{H}_{2}$ (dashed line) all measured at $673 \mathrm{~K}$. (C) Fourier transform $\left(k^{2}, \Delta k=3.7-14.5 \AA^{-1}\right)$ of sulfided $\mathrm{Mo} / \mathrm{Al}_{2} \mathrm{O}_{3}$ after reduction with $\mathrm{H}_{2}$ (solid line) and best fit (dotted line).

Figure 1b. The Fourier transform is $k^{1}$ weighted to emphasize changes in the first shell due to Mo-S scattering at $2.41 \AA$. As shown, the amplitude of the peak characterizing the Mo-S first shell slightly decreased upon treatment with $\mathrm{H}_{2}$ (compare thin solid line with dotted line). Subsequent exposure to thiophene/ $\mathrm{H}_{2}$ (thick solid line) increased the amplitude again, which is likely to be due to incorporation of sulfur. However, the change of the amplitude cannot be related directly to the coordination number since the amplitude of the Fourier transform is proportional to $N / \Delta \sigma .^{2}$ The amplitude depends therefore both on the Debye-Waller factor and the coordination number. Accordingly, analysis of the data (see Table 2) shows that the changes in $\mathrm{Mo}-\mathrm{S}$ coordination number $\left(\mathrm{N}_{\mathrm{Mo}-\mathrm{S}}\right)$ remained within the limits of experimental error. A change of $N_{\mathrm{Mo}-\mathrm{S}}$ from 5.0 to 4.8 upon reduction and back to 5.1 upon exposition to thiophene cannot be considered to be significant. An example of the good quality of the fits is shown in Figure 1c, which displays the $k^{2}$ weighted Fourier transform of the data for the sample under $\mathrm{H}_{2}$ (solid line) together with the best fit (dotted 
TABLE 2: Fit Parameters Mo-K Edge $\mathrm{Mo} / \mathrm{Al}_{2} \mathrm{O}_{3}$ : Sulfidation, Reduction, and Thiophene

\begin{tabular}{|c|c|c|c|c|c|c|}
\hline scatterer & $N$ & $\begin{array}{c}\Delta \sigma^{2} \\
\left(10^{-4} \AA^{2}\right)\end{array}$ & $\begin{array}{c}R \\
(\AA)\end{array}$ & $\begin{array}{l}\Delta E_{0} \\
(\mathrm{eV})\end{array}$ & $\begin{array}{l}\text { var } \\
\operatorname{im}^{a}\end{array}$ & $\begin{array}{l}\text { var } \\
\mathrm{ab}^{a}\end{array}$ \\
\hline \multicolumn{5}{|c|}{$\mathrm{Mo} / \mathrm{Al}_{2} \mathrm{O}_{3}$ sulfided $673 \mathrm{~K}, k^{2}$} & 0.81 & 0.51 \\
\hline $\mathrm{Mo}-\mathrm{O}$ & 0.5 & 84.7 & 1.99 & 0.9 & & \\
\hline $\mathrm{Mo}-\mathrm{S}$ & 5.0 & 49.8 & 2.41 & 1.8 & & \\
\hline $\mathrm{Mo}-\mathrm{Mo}$ & 2.9 & 76.0 & 3.16 & 2.2 & & \\
\hline \multicolumn{5}{|c|}{$\mathrm{Mo} / \mathrm{Al}_{2} \mathrm{O}_{3}$ reduction $\mathrm{H}_{2} 673 \mathrm{~K}, k^{2}$} & 0.90 & 0.56 \\
\hline $\mathrm{Mo}-\mathrm{O}$ & 0.5 & 91.7 & 1.99 & 5.0 & & \\
\hline $\mathrm{Mo}-\mathrm{S}$ & 4.8 & 53.7 & 2.41 & 1.4 & & \\
\hline Mo-Mo & 2.8 & 84.1 & 3.16 & 2.5 & & \\
\hline \multicolumn{5}{|c|}{$\mathrm{Mo} / \mathrm{Al}_{2} \mathrm{O}_{3}$ thiophene $/ \mathrm{H}_{2} 673 \mathrm{~K}, k^{2}$} & 0.67 & 0.42 \\
\hline $\mathrm{Mo}-\mathrm{O}$ & 0.5 & 101.6 & 1.99 & 0.7 & & \\
\hline $\mathrm{Mo}-\mathrm{S}$ & 5.1 & 47.6 & 2.41 & 2.0 & & \\
\hline $\mathrm{Mo}-\mathrm{Mo}$ & 3.1 & 74.2 & 3.16 & 2.3 & & \\
\hline
\end{tabular}

${ }^{a}$ Variance imaginary and absolute part Fourier transform.

TABLE 3: Fit Parameters Co K-edge $\mathrm{CoMo} / \mathrm{Al}_{2} \mathrm{O}_{3}$ : Sulfidation, Reduction and Thiophene

\begin{tabular}{|c|c|c|c|c|c|c|}
\hline scatterer & $N$ & $\begin{array}{c}\Delta \sigma^{2} \\
\left(10^{-4} \AA^{2}\right)\end{array}$ & $\begin{array}{c}R \\
(\AA)\end{array}$ & $\begin{array}{l}\Delta E_{0} \\
(\mathrm{eV})\end{array}$ & $\begin{array}{l}\text { var } \\
\operatorname{im}^{a}\end{array}$ & $\begin{array}{l}\mathrm{var} \\
\mathrm{ab}^{a}\end{array}$ \\
\hline \multicolumn{5}{|c|}{$\mathrm{CoMo} / \mathrm{Al}_{2} \mathrm{O}_{3}$ Sulfided $673 \mathrm{~K}, k^{3}$} & 0.66 & 0.21 \\
\hline $\mathrm{Co}-\mathrm{S}$ & 6.0 & 94.6 & 2.16 & 9.7 & & \\
\hline $\mathrm{Co}-\mathrm{Co}$ & 1.5 & 110.1 & 2.42 & -1.0 & & \\
\hline $\mathrm{Co}-\mathrm{Mo}$ & 1.2 & 81.4 & 2.77 & 6.2 & & \\
\hline $\mathrm{Co}-\mathrm{Co}$ & 2.9 & 4.2 & 3.47 & 10.0 & & \\
\hline \multicolumn{5}{|c|}{$\mathrm{CoMo} / \mathrm{Al}_{2} \mathrm{O}_{3}$ Reduction $\mathrm{H}_{2} 673 \mathrm{~K}, k^{3}$} & 1.90 & 0.52 \\
\hline $\mathrm{Co}-\mathrm{S}$ & 5.2 & 88.5 & 2.16 & 9.8 & & \\
\hline $\mathrm{Co}-\mathrm{Co}$ & 1.4 & 1.2 & 2.38 & -1.0 & & \\
\hline $\mathrm{Co}-\mathrm{Mo}$ & 1.2 & 74.2 & 2.75 & 6.3 & & \\
\hline $\mathrm{Co}-\mathrm{Co}$ & 2.6 & 32.5 & 3.47 & 10.0 & & \\
\hline \multicolumn{5}{|c|}{$\mathrm{CoMo} / \mathrm{Al}_{2} \mathrm{O}_{3}$ Thiophene $/ \mathrm{H}_{2} 673 \mathrm{~K}, k^{3}$} & 2.01 & 0.80 \\
\hline $\mathrm{Co}-\mathrm{S}$ & 5.4 & 89.3 & 2.16 & 10.0 & & \\
\hline $\mathrm{Co}-\mathrm{Co}$ & 1.3 & 108.9 & 2.38 & 1.1 & & \\
\hline $\mathrm{Co}-\mathrm{Mo}$ & 1.4 & 67.6 & 2.75 & 7.1 & & \\
\hline $\mathrm{Co}-\mathrm{Co}$ & 2.7 & 25.8 & 3.47 & 9.8 & & \\
\hline
\end{tabular}

${ }^{a}$ Variance imaginary and absolute part Fourier transform.

line). Data obtained at the $\mathrm{Mo}-\mathrm{K}$ edge with $\mathrm{CoMo} / \mathrm{Al}_{2} \mathrm{O}_{3}$ gave similar results.

In contrast to the Mo results, the effects of the different treatments were more significant on the data obtained at the $\mathrm{Co}-\mathrm{K}$ edge for $\mathrm{CoMo} / \mathrm{Al}_{2} \mathrm{O}_{3}$. As Figure $2 \mathrm{a}$ demonstrates, the quality of the data at the Co edge was also high. The changes in the amplitude of the Fourier transform are shown in Figure 2b. When the sample was exposed at $673 \mathrm{~K}$ to the $\mathrm{H}_{2}$ flow, the $\mathrm{Co}-\mathrm{S}$ coordination dropped significantly from 6.0 to 5.2 (see Table 3). Subsequent exposure to a thiophene-containing $\mathrm{H}_{2}$ flow increased the coordination number to a value of 5.4, which is within the limits of accuracy the same as 5.2. Thus, under both $\mathrm{H}_{2}$ and thiophene/ $\mathrm{H}_{2}$, the sulfur coordination was below that of the freshly sulfided sample, clearly pointing to generation of sulfur vacancies on the Co atoms. The second coordination shell could be fitted with two $\mathrm{Co}-\mathrm{Co}$ and one $\mathrm{Co}-$ Mo contribution at 2.42, 3.47, and $2.77 \AA$, respectively (Table 3). Bulk $\mathrm{Co}_{9} \mathrm{~S}_{8}$ contains two $\mathrm{Co}-\mathrm{Co}$ contributions at bond distances of 2.51 and $3.54 \AA$, while a Co-Mo bond distance of $2.80 \AA$ was reported for the "Co-Mo-S" phase in $\mathrm{Co}-$ $\mathrm{Mo} / \mathrm{C}$ catalysts. ${ }^{24}$ The structure of the cobalt sulfide phase in this $\mathrm{CoMo} / \mathrm{Al}_{2} \mathrm{O}_{3}$ catalyst can therefore best be described as a mixture of a bulklike cobalt sulfide and a "Co-Mo-S" phase. Since no special procedures were used during the preparation of this catalyst to optimize the $\mathrm{Co}-\mathrm{Mo}$ interaction, the presence of $\mathrm{Co}_{9} \mathrm{~S}_{8}$ was not surprising.

Characterization of Sulfided Com-CoMo/ $/ \mathrm{Al}_{2} \mathrm{O}_{3}$. The data obtained at the Mo- $\mathrm{K}$ edge of the commercial CoMo catalyst are similar to those obtained with the $\mathrm{Mo} / \mathrm{Al}_{2} \mathrm{O}_{3}$ catalyst as can be seen in Figure 3 and Table 4 (center). The Mo-Mo coordination number of 2.5 points to molybdenum sulfide
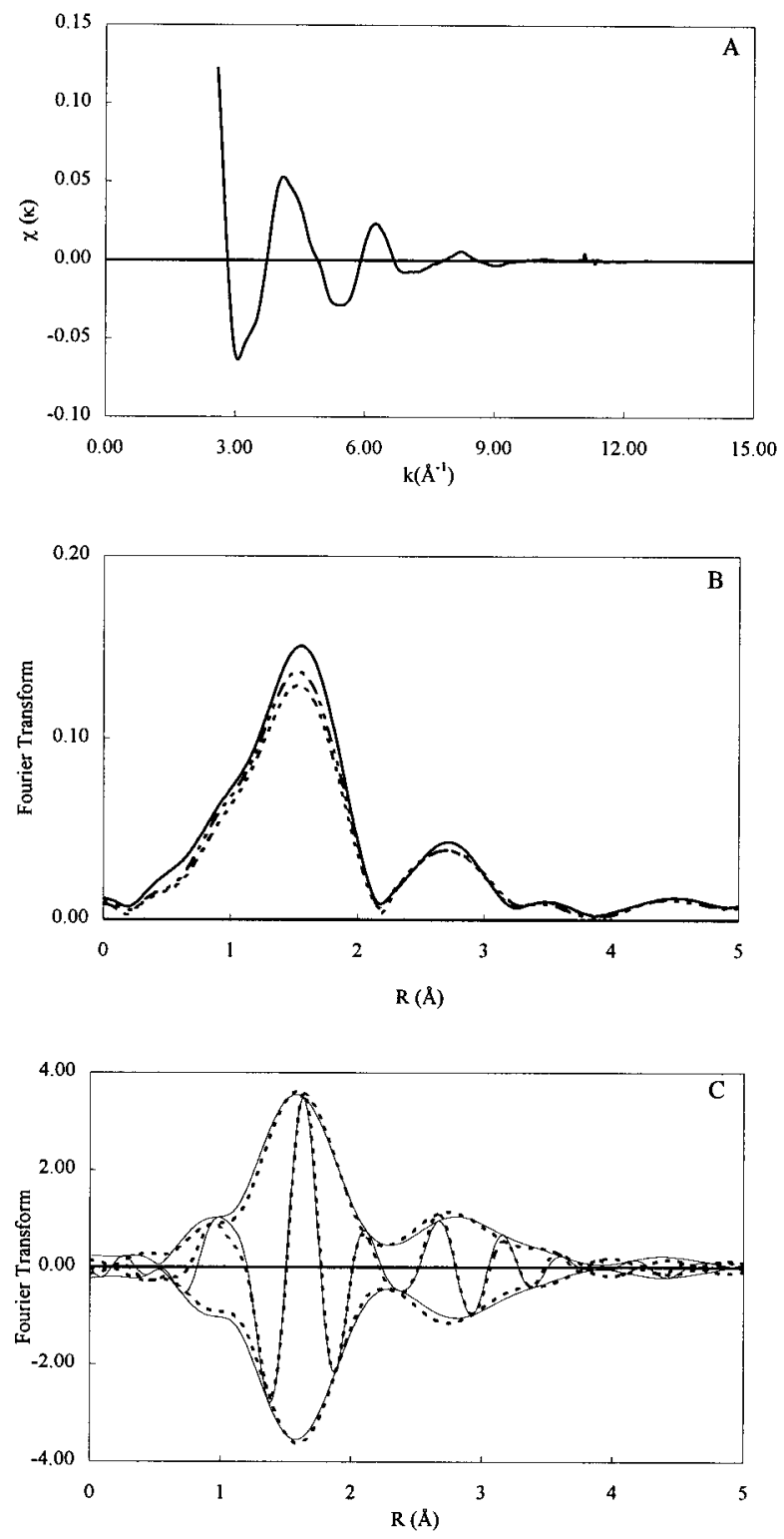

Figure 2. (A) $\mathrm{Co}-\mathrm{K}$ EXAFS spectrum (unweighted) of sulfided $\mathrm{CoMo} / \mathrm{Al}_{2} \mathrm{O}_{3}$ measured at $673 \mathrm{~K}$. (B) Absolute part of Fourier transform $\left(k^{1}, \Delta k=3.0-10.0 \AA^{-1}\right)$ of sulfided $\mathrm{CoMo} / \mathrm{Al}_{2} \mathrm{O}_{3}$ (solid line) after reduction with $\mathrm{H}_{2}$ (dotted line) and after exposition to thiophene/ $\mathrm{H}_{2}$ (dashed line), all measured at $673 \mathrm{~K}$. (C) Fourier transform $\left(k^{3}, \Delta k=\right.$ 3.0-10.0 $\AA^{-1}$ ) of sulfided $\mathrm{Mo} / \mathrm{Al}_{2} \mathrm{O}_{3}$ after reduction with $\mathrm{H}_{2}$ (solid line) and best fit (dotted line).

TABLE 4: Fit Parameters Mo-K Edge (com-Co) $\mathrm{Mo} / \mathrm{Al}_{2} \mathrm{O}_{3}$ : TPS and Selenophene Treatment

\begin{tabular}{|c|c|c|c|c|c|c|}
\hline scatterer & $N$ & $\begin{array}{c}\Delta \sigma^{2} \\
\left(10^{-4} \AA^{2}\right) \\
\end{array}$ & $\begin{array}{c}R \\
(\AA) \\
\end{array}$ & $\begin{array}{l}\Delta E_{0} \\
(\mathrm{eV})\end{array}$ & $\begin{array}{l}\text { var } \\
\operatorname{im}^{a} \\
\end{array}$ & $\begin{array}{l}\text { var } \\
\mathrm{ab}^{a} \\
\end{array}$ \\
\hline \multicolumn{5}{|c|}{$\mathrm{Mo}-\mathrm{K}$ edge $\mathrm{Mo} / \mathrm{Al}_{2} \mathrm{O}_{3} \mathrm{HD}$-Se $673 \mathrm{~K}, k^{2}$} & 0.46 & 0.32 \\
\hline $\mathrm{Mo}-\mathrm{S}$ & 4.4 & 11.1 & 2.43 & -0.9 & & \\
\hline $\mathrm{Mo}-\mathrm{Se}$ & 1.6 & 54.9 & 2.50 & 1.5 & & \\
\hline Mo-Mo & 3.4 & 24.6 & 3.16 & 2.0 & & \\
\hline \multicolumn{5}{|c|}{$\mathrm{Mo}-\mathrm{K}$ edge com-CoMo/ $/ \mathrm{Al}_{2} \mathrm{O}_{3}$ sulfided at $673 \mathrm{~K}, k^{2}$} & 0.65 & 0.28 \\
\hline $\mathrm{Mo}-\mathrm{O}$ & 0.2 & 17.6 & 1.99 & -5.4 & & \\
\hline $\mathrm{Mo}-\mathrm{S}$ & 4.9 & 15.8 & 2.41 & 3.9 & & \\
\hline Mo-Mo & 2.5 & 21.0 & 3.16 & 1.7 & & \\
\hline \multicolumn{5}{|c|}{$\mathrm{Mo}-\mathrm{K}$ edge com-CoMo/ $/ \mathrm{Al}_{2} \mathrm{O}_{3} \mathrm{HD}-\mathrm{Se} 673 \mathrm{~K}, k^{2}$} & 0.50 & 0.25 \\
\hline $\mathrm{Mo}-\mathrm{S}$ & 5.3 & 31.4 & 2.43 & -0.5 & & \\
\hline $\mathrm{Mo}-\mathrm{Se}$ & 1.1 & 16.0 & 2.52 & -5.7 & & \\
\hline Mo-Mo & 2.9 & 22.6 & 3.16 & 2.6 & & \\
\hline
\end{tabular}

${ }^{a}$ Variance imaginary and absolute part Fourier transform.

particles containing about three or four Mo atoms per slab. Figure 3c displays the EXAFS data obtained at the Co K-edge for com-CoMo/ $\mathrm{Al}_{2} \mathrm{O}_{3}$. Analysis of the data (see Table 5, top) 

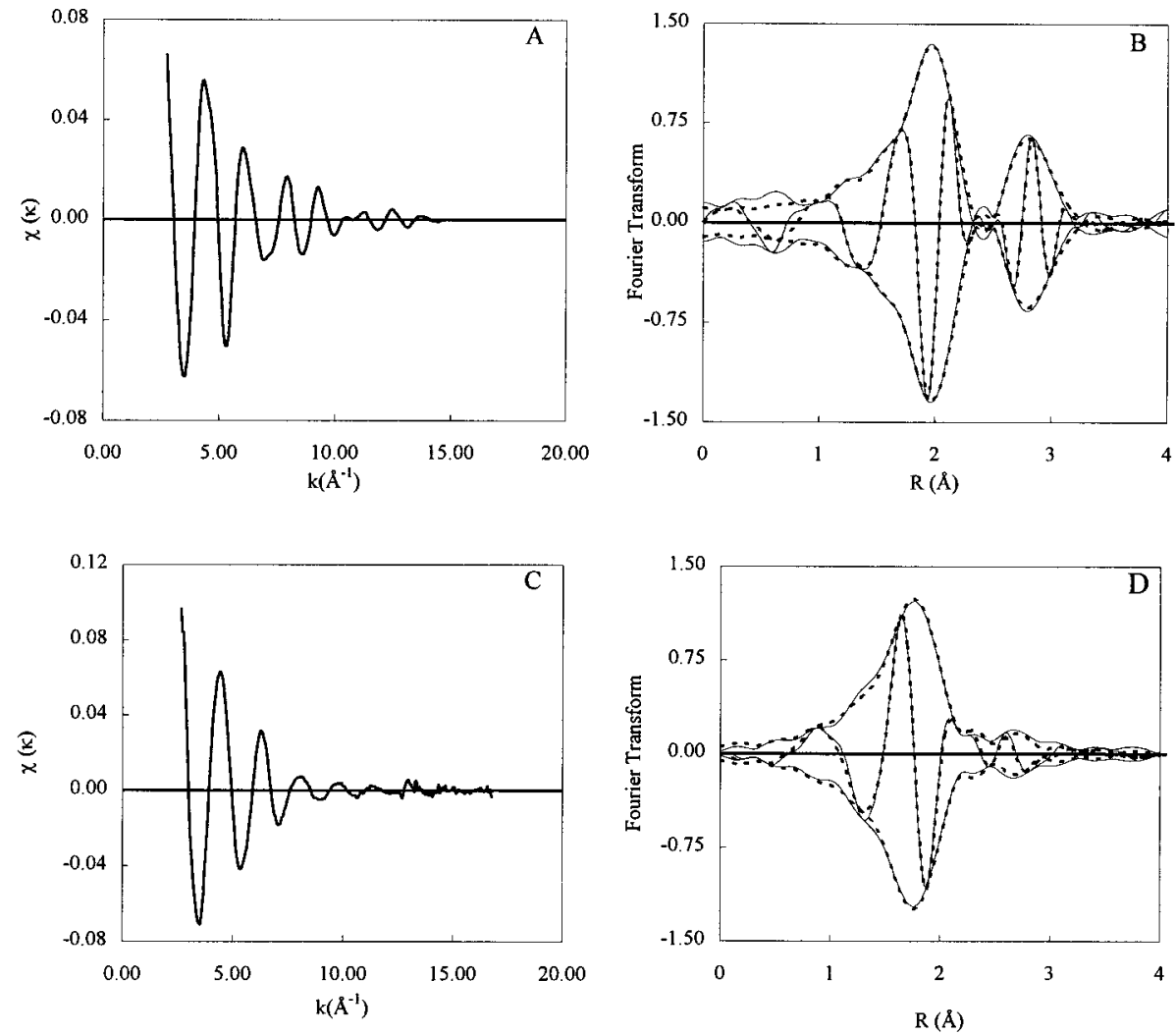

Figure 3. (A) Mo-K EXAFS spectrum (unweighted) of sulfided com-CoMo/ $\mathrm{Al}_{2} \mathrm{O}_{3}$ measured at $77 \mathrm{~K}$. (B) Corresponding Fourier transform ( $k^{2}$, $\Delta k=4.0-14.0 \AA^{-1}$ ) (solid line) and best fit (dotted line). (C) Co-K EXAFS spectrum (unweighted) of sulfided com-CoMo/ $\mathrm{Al}_{2} \mathrm{O}_{3}$. (D) $\mathrm{Corresponding}$ Fourier transform $\left(k^{2}, \Delta k=3.0-12.0 \AA^{-1}\right)$ (solid line) and best fit (dotted line).

TABLE 5: Fit Parameters Co-K Edge Com-CoMo/Al $\mathbf{A O}_{2}$ : TPS and Selenophene Treatment

\begin{tabular}{|c|c|c|c|c|c|c|}
\hline scatterer & $N$ & $\begin{array}{c}\Delta \sigma^{2} \\
\left(10^{-4} \AA^{2}\right)\end{array}$ & $\begin{array}{c}R \\
(\AA)\end{array}$ & $\begin{array}{l}\Delta E_{0} \\
(\mathrm{eV})\end{array}$ & $\begin{array}{l}\text { var } \\
\operatorname{im}^{a}\end{array}$ & $\begin{array}{l}\text { var } \\
a^{a}{ }^{a}\end{array}$ \\
\hline \multicolumn{5}{|c|}{$\mathrm{Co}-\mathrm{K}$ edge com-CoMo$/ \mathrm{Al}_{2} \mathrm{O}_{3}$ sulfided $673 \mathrm{~K}, k^{3}$} & 1.33 & 0.61 \\
\hline $\mathrm{Co}-\mathrm{S}$ & 5.2 & 30.3 & 2.21 & -0.7 & & \\
\hline $\mathrm{Co}-\mathrm{Mo}$ & 1.1 & 66.6 & 2.81 & -4.2 & & \\
\hline \multicolumn{5}{|c|}{$\mathrm{Co}-\mathrm{K}$ edge com-CoMo/ $/ \mathrm{Al}_{2} \mathrm{O}_{3} \mathrm{HD}-\mathrm{Se} 673 \mathrm{~K}, k^{3}$} & 1.06 & 0.47 \\
\hline $\mathrm{Co}-\mathrm{S}$ & 1.8 & -25.4 & 2.20 & 4.5 & & \\
\hline $\mathrm{Co}-\mathrm{Se}$ & 1.9 & 16.3 & 2.35 & -4.4 & & \\
\hline $\mathrm{Co}-\mathrm{Mo}$ & 1.4 & -3.8 & 3.28 & -2.6 & & \\
\hline
\end{tabular}

${ }^{a}$ Variance imaginary and absolute part Fourier transform.

of the sulfided sample indicated that in this catalyst all cobalt is present in a "Co-Mo-S" structure. Each Co atom is surrounded by five $\mathrm{S}$ neighbors at $2.21 \AA$. Further, one Mo backscatterer is present at $2.81 \AA$ in agreement with literature data. $^{24}$ No Co-Co contributions were observed in the commercial catalyst, indicating the absence of $\mathrm{Co}_{9} \mathrm{~S}_{8}$. In the following sections only the results of the commercial CoMo catalyst will be presented.

Catalytic Activity and Selenophene Adsorption. To study the catalytic activity of $\mathrm{CoMo}$ in $\mathrm{HD}-\mathrm{Se}$ the conversion of selenophene was measured as a function of temperature and compared to that of thiophene. Figure 4 shows the conversion curve of thiophene and selenophene for com-CoMo/ $\mathrm{Al}_{2} \mathrm{O}_{3}$ at temperatures between 373 and $673 \mathrm{~K}\left(\mathrm{sv}=3000 \mathrm{~h}^{-1}\right)$. The products that were observed in both reactions were the regular HDS products, such as, cis/trans-1-butene, butane, and $\mathrm{H}_{2} \mathrm{~S}$ / $\mathrm{H}_{2} \mathrm{Se}$. Initially, only $\mathrm{H}_{2} \mathrm{~S}$ was observed with the conversion of selenophene. This indicated that $\mathrm{Se}$ had a finite residence time on the surface of the catalyst. From Figure 4 it may be concluded that HDS of thiophene is more difficult than HD-Se of selenophene (apparent activation energy $E_{\mathrm{a}}$ of 107 and 88 $\mathrm{kJ} / \mathrm{mol}$, respectively). Although there is a difference in reactivity, the experiment of Figure 4 illustrates that selenophene is

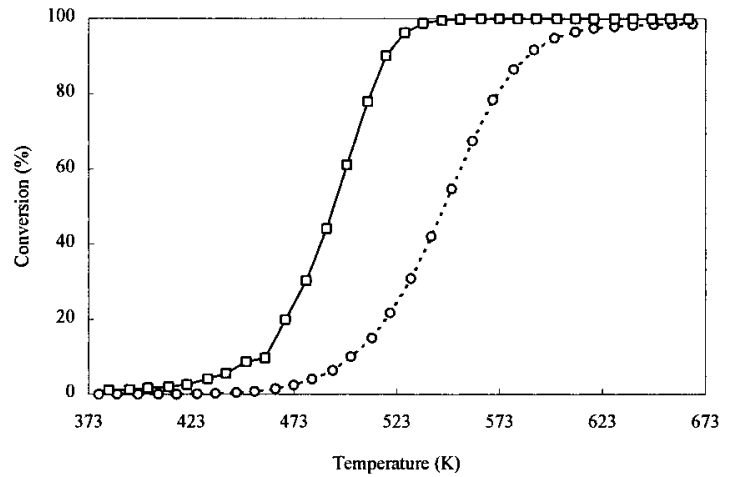

Figure 4. Conversion curves of com-CoMo/ $\mathrm{Al}_{2} \mathrm{O}_{3}$ in $\mathrm{HDS}$ of thiophene (open circles) and HD-Se of selenophene (open squares) (space velocity $\left.=3000 \mathrm{~h}^{-1}, 1 \mathrm{~atm}\right)$.

representative of thiophene, reacting in a similar way over a HDS catalyst. Moreover, Se is incorporated into the structure of the catalyst, which makes characterization with EXAFS interesting.

To check at which temperature all selenophene was desorbed from the catalyst surface, a temperature-programmed desorption (TPD) profile was recorded. Figure 5 shows the desorption profile of selenophene as a function of the catalyst temperature. Obviously, practically all physisorbed selenophene was removed from the catalyst at $423 \mathrm{~K}$. For reasons of safety no in situ experiments at reaction temperatures were performed at the beam line. Both $\mathrm{H}_{2} \mathrm{Se}$ and its decomposition product $\mathrm{Se}$ are toxic.

HD-Se on $\mathrm{Mo} / \mathrm{Al}_{2} \mathrm{O}_{3}$. After sulfidation $\mathrm{Mo} / \mathrm{Al}_{2} \mathrm{O}_{3}$ was exposed to selenophene $/ \mathrm{H}_{2}$ at $673 \mathrm{~K}$ during $60 \mathrm{~min}$. Before cooling down to liquid nitrogen temperature the EXAFS cell was flushed with $\mathrm{He}$ flow at $423 \mathrm{~K}$ during $30 \mathrm{~min}$ to remove physisorbed selenophene. The sample was characterized at 77 $\mathrm{K}$ at both the Mo and the $\mathrm{Se}-\mathrm{K}$ edge. Figure 6a,b displays 


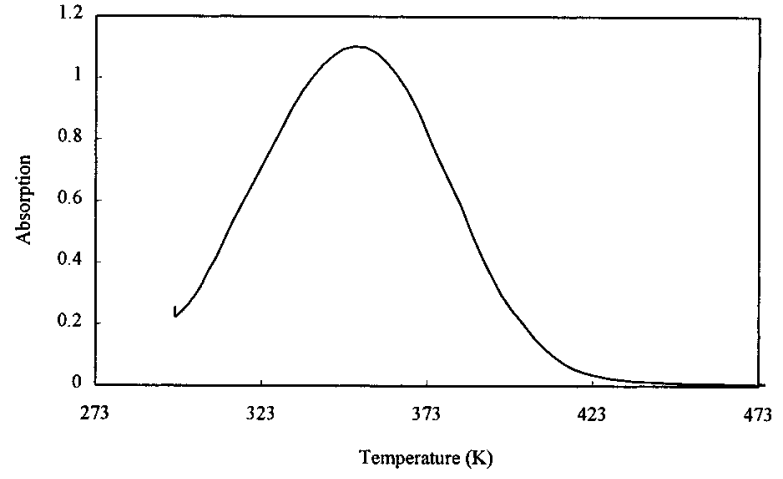

Figure 5. Temperature-programmed desorption profile of selenophene adsorbed on sulfided com- $\mathrm{CoMo} / \mathrm{Al}_{2} \mathrm{O}_{3}$ catalyst measured spectrophotometrically at $\lambda=232 \mathrm{~nm}$. the raw Mo EXAFS data and the corresponding Fourier transforms. For comparison, the $\mathrm{Mo}-\mathrm{K}$ edge data are also shown for the sample sulfided at $673 \mathrm{~K}$ and characterized at 77 $\mathrm{K}$. Upon exposure to selenophene, a clear increase was observed in the amplitude of the Fourier transform between 2.0 and $2.5 \AA$. Data analysis (see Table 4) showed that this amplitude change can be ascribed to the partial substitution of $\mathrm{S}$ atoms at $2.41 \AA$ by Se at a bond distance of $2.50 \AA$. As is shown in Figure 6c, S and $\mathrm{Se}$ (atomic number 16 and 34, respectively) can easily be distinguished from one another due to both a different phase shift and backscattering amplitude. To equally emphasize the Mo-S and Mo-Se contributions the $k^{2}$ weighted Fourier transforms were analyzed. Figure 6d,e displays the Fourier transforms of the difference files and the calculated $\mathrm{Mo}-\mathrm{S}$ and $\mathrm{Mo}-\mathrm{Se}$ contributions, respectively. The
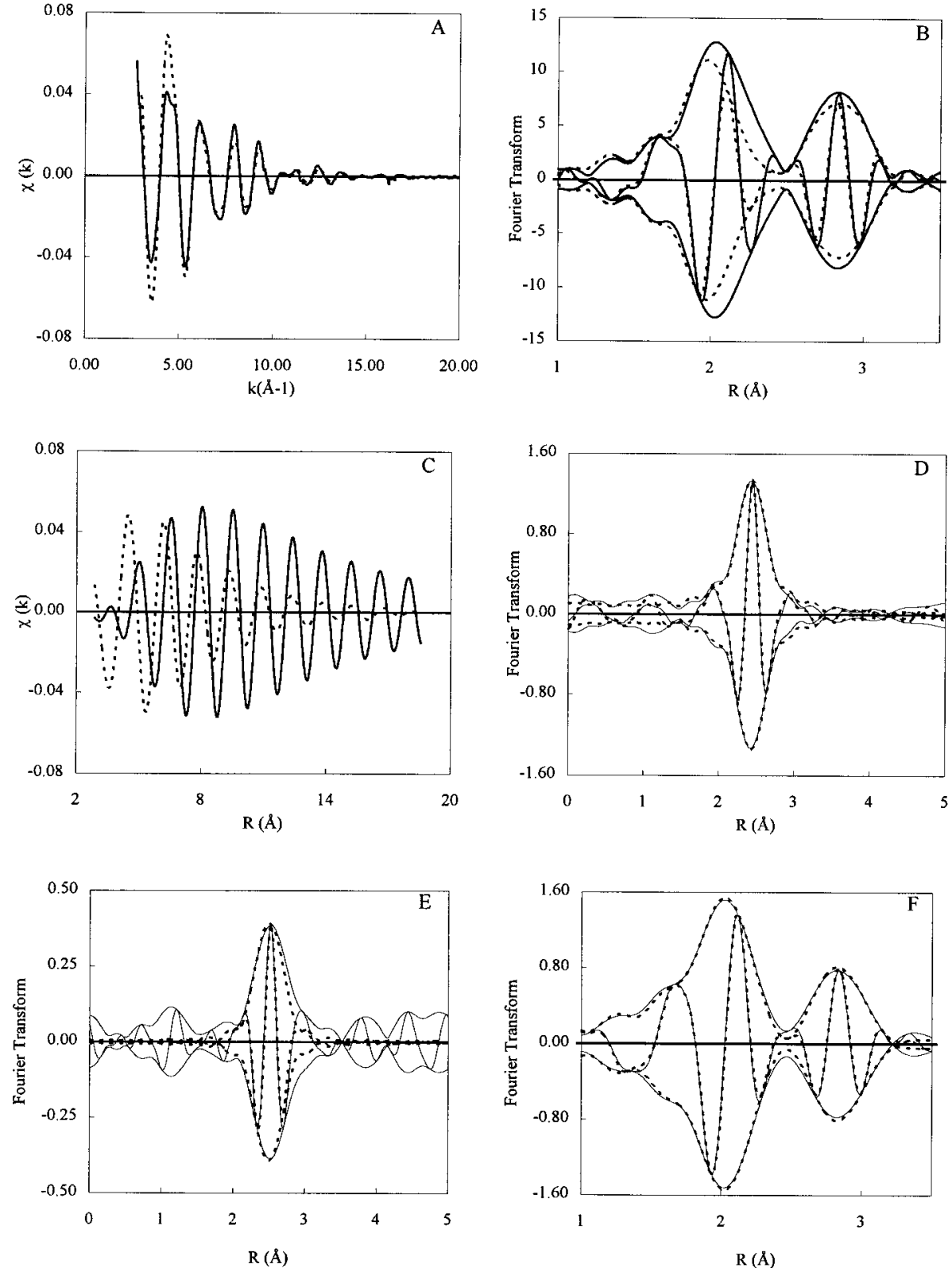

Figure 6. (A) Mo-K EXAFS spectra (unweighted) of sulfided $\mathrm{Mo} / \mathrm{Al}_{2} \mathrm{O}_{3}$ (dotted line) and after $\mathrm{HD}-\mathrm{Se}$ at $673 \mathrm{~K}$ (solid line) measured at $673 \mathrm{~K}$. (B) Fourier transforms $\left(k^{3}, \Delta k=3.2-16.0 \AA^{-1}\right.$ ) of sulfided $\mathrm{Mo}_{\mathrm{Al}} \mathrm{O}_{3}$ (dotted line) and after HD-Se at $673 \mathrm{~K}$ (solid line). (C) EXAFS spectra of calculated $\mathrm{Mo}-\mathrm{S}$ (dotted line) and $\mathrm{Mo}-\mathrm{Se}$ (solid line) contributions $\left(N=1, \Delta \sigma^{2}=0, R(\mathrm{Mo}-\mathrm{S})=2.41 \AA, R(\mathrm{Mo}-\mathrm{Se})=2.50 \AA, \Delta E_{\mathrm{o}}=0\right)$. (D) Fourier transform $\left(k^{2}, \Delta k=4.0-14.0 \AA^{-1}\right.$, Mo-S phase corrected) of Mo-S contribution for sulfided $\mathrm{Mo} / \mathrm{Al}_{2} \mathrm{O}_{3}$ after $\mathrm{HD}-\mathrm{Se}$ at $673 \mathrm{~K}$; difference file: EXAFS spectrum minus calculated $\mathrm{Mo}-\mathrm{Se}$ and Mo-Mo contribution (solid line) and Mo-S fit (dotted line). (E) Fourier transform ( $k^{2}, \Delta k$ $=4.0-14.0 \AA^{-1}, \mathrm{Mo}-$ Se phase corrected) of Mo-Se contribution; difference: EXAFS spectrum minus calculated Mo-S and Mo-Mo contributions (solid line) and Mo-Se fit (dotted line). (F) Fourier transform $\left(k^{2}, \Delta k=4.0-14.0 \AA^{-1}\right.$ ) of sulfided $\mathrm{Mo}^{-} \mathrm{Al}_{2} \mathrm{O}_{3}$ after $\mathrm{HD}-\mathrm{Se}$ at $673 \mathrm{~K}$ (solid line) and best fit (dotted line). 

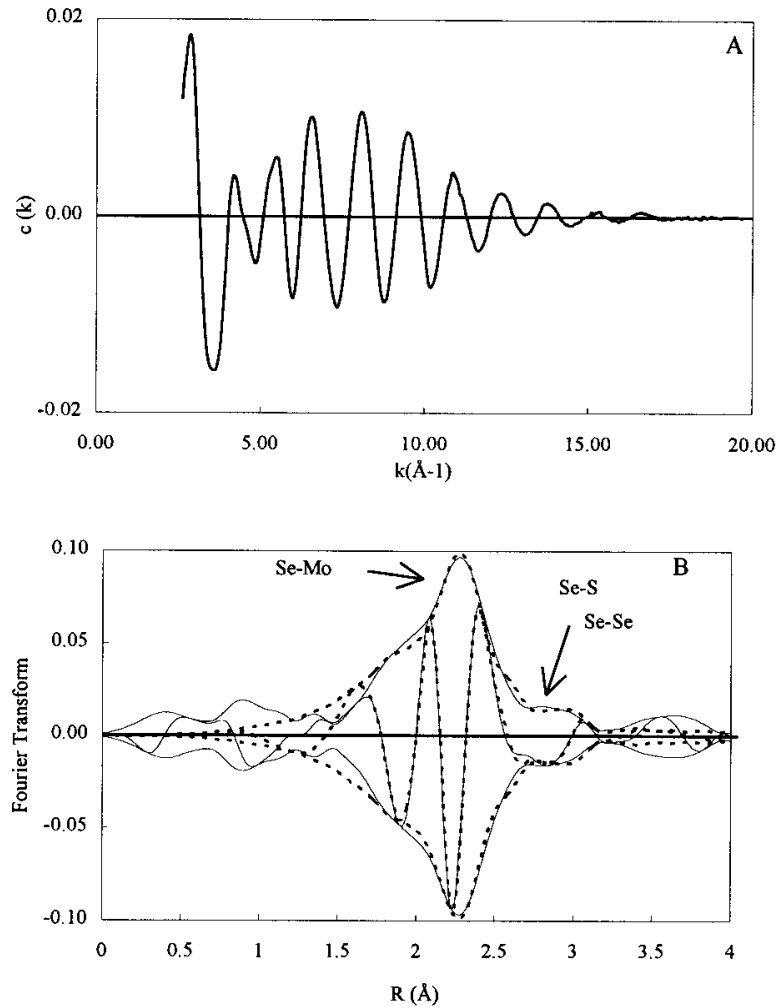

Figure 7. (A) $\mathrm{Se}-\mathrm{K}$ EXAFS spectrum (unweighted) of sulfided $\mathrm{Mo} /$ $\mathrm{Al}_{2} \mathrm{O}_{3}$ after HD-Se at $673 \mathrm{~K}$. (B) Corresponding Fourier transform $\left(k^{1}\right.$, $\left.\Delta k=3.4-14.0 \AA^{-1}\right)$ (solid line) and best fit (dotted line).

TABLE 6: Fit Parameters $\mathrm{Se}-\mathrm{K}$ edge $(\mathrm{Com}-\mathrm{Co}) \mathrm{Mo} / \mathrm{Al}_{2} \mathrm{O}_{3}$ : Selenophene Treatment

\begin{tabular}{|c|c|c|c|c|c|c|}
\hline scatterer & $N$ & $\begin{array}{c}\Delta \sigma^{2} \\
\left(10^{-4} \AA^{2}\right)\end{array}$ & $\begin{array}{c}R \\
(\AA)\end{array}$ & $\begin{array}{l}\Delta E_{0} \\
(\mathrm{eV})\end{array}$ & $\begin{array}{l}\text { var } \\
\text { im }^{a}\end{array}$ & $\begin{array}{l}\text { var } \\
\mathrm{ab}^{a}\end{array}$ \\
\hline \multicolumn{5}{|c|}{$\mathrm{Mo} / \mathrm{Al}_{2} \mathrm{O}_{3} \mathrm{HD}-\mathrm{Se} 673 \mathrm{~K}, k^{1}$} & 1.08 & 0.83 \\
\hline $\mathrm{Se}-\mathrm{Mo}$ & 2.4 & 38.8 & 2.51 & 5.2 & & \\
\hline $\mathrm{Se}-\mathrm{S}$ & 4.5 & 168.3 & 3.18 & 11.6 & & \\
\hline $\mathrm{Se}-\mathrm{Se}$ & 0.7 & 57.6 & 3.28 & -3.1 & & \\
\hline $\mathrm{Se}-\mathrm{Se}$ & 1.5 & 78.1 & 4.09 & 8.5 & & \\
\hline \multicolumn{5}{|c|}{ com-CoMo/ $/ \mathrm{Al}_{2} \mathrm{O}_{3} \mathrm{HD}-\mathrm{Se} 473 \mathrm{~K}, k^{1}$} & 1.13 & 0.48 \\
\hline $\mathrm{Se}-\mathrm{C}$ & 1.0 & 36.5 & 1.71 & -6.9 & & \\
\hline $\mathrm{Se}-\mathrm{Co}$ & 1.0 & 10.7 & 2.39 & -5.6 & & \\
\hline $\mathrm{Se}-\mathrm{S}$ & 0.8 & 64.2 & 2.89 & 1.3 & & \\
\hline \multicolumn{5}{|c|}{ com-CoMo/ $/ \mathrm{Al}_{2} \mathrm{O}_{3} \mathrm{HD}-\mathrm{Se} 673 \mathrm{~K}, k^{1}$} & 0.42 & 0.26 \\
\hline $\mathrm{Se}-\mathrm{Co}$ & 1.0 & 14.0 & 2.35 & -9.1 & & \\
\hline $\mathrm{Se}-\mathrm{Mo}$ & 1.0 & 16.1 & 2.55 & -7.9 & & \\
\hline $\mathrm{Se}-\mathrm{S}$ & 0.3 & 18.8 & 3.15 & -2.4 & & \\
\hline $\mathrm{Se}-\mathrm{Se}$ & 0.5 & 70.1 & 3.28 & -6.5 & & \\
\hline $\mathrm{Se}-\mathrm{Se}$ & 4.5 & 183.4 & 4.10 & 8.01 & & \\
\hline
\end{tabular}

${ }^{a}$ Variance imaginary and absolute part Fourier Transform

perfect agreement between the experimental data and total fit can be seen in Figure 6f.

Comparison of the sample after HD-Se (Table 4) with the sulfided sample (Table 2) shows that after HD-Se the Mo-Mo coordination number has increased to 3.4 as compared to 2.9 after sulfidation, while HD-Se also leads to a loss of the Mo-O contribution. Addition of a $\mathrm{Mo}-\mathrm{O}$ contribution to the fit of the spectrum of the HD-Se sample did not lead to a significant improvement of the quality of the fit. Since the change of the Mo-Mo coordination number is fairly small, the particle sizes of the $\mathrm{MoS}_{2}$ slabs are comparable. Therefore, stacking of the slabs most likely has proceeded, causing a lower and thus nonsignificant $\mathrm{Mo}-\mathrm{O}_{\text {support }}$ contribution.

Data obtained at the Se edge with $\mathrm{Mo} / \mathrm{Al}_{2} \mathrm{O}_{3}$ are represented in Figure 7 and Table 6 . The main feature in the Fourier transform is the peak at about $2.2 \AA$ due to a Mo backscatterer at a bond distance of $2.51 \AA$. The data at the Se edge thus
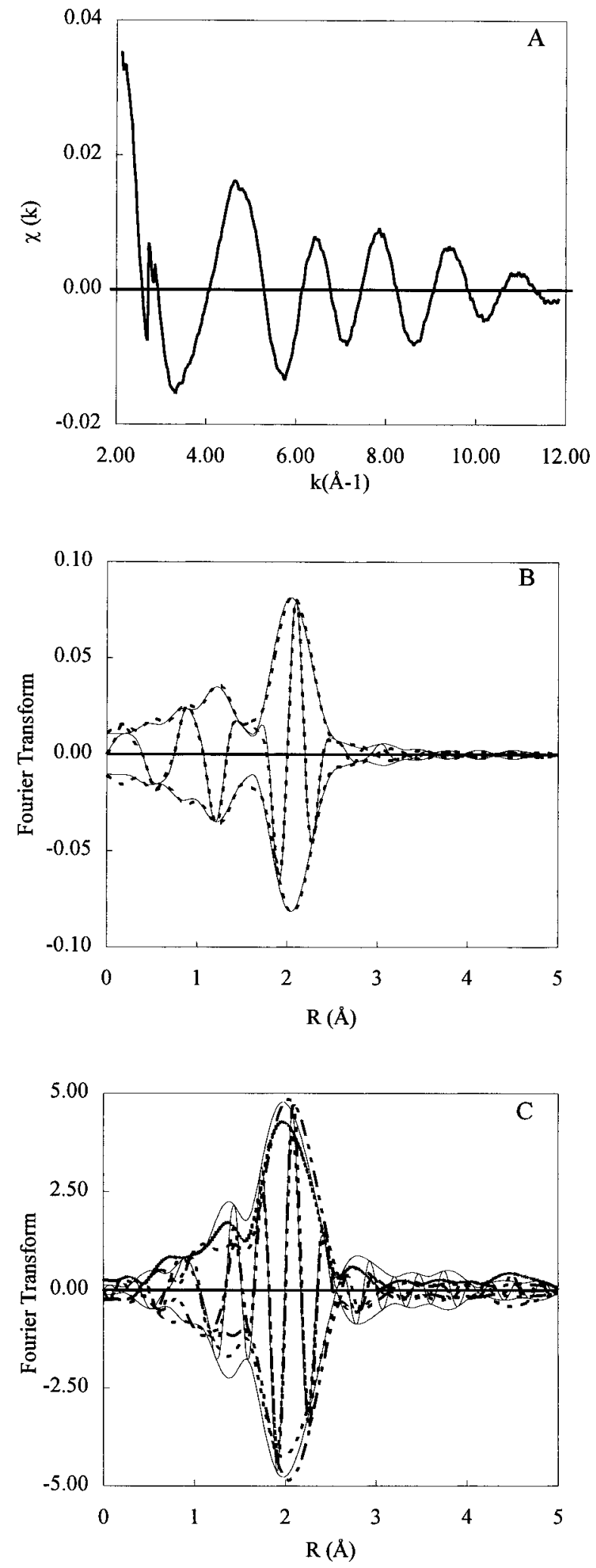

Figure 8. (A) $\mathrm{Se}-\mathrm{K}$ EXAFS spectrum (unweighted) of sulfided com$\mathrm{CoMo} / \mathrm{Al}_{2} \mathrm{O}_{3}$ after $\mathrm{HD}-\mathrm{Se}$ at $473 \mathrm{~K}$. (B) Corresponding Fourier transform $\left(k^{1}, \Delta k=3.4-14.0 \AA^{-1}\right)$ (solid line) and best fit (dotted line). (C) Fourier transforms $\left(k^{3}, \Delta k=2.9-12.0 \AA^{-1}\right)$ of sulfided com$\mathrm{CoMo} / \mathrm{Al}_{2} \mathrm{O}_{3}$ after HD-Se at $473 \mathrm{~K}, \Delta \mu \mathrm{x}=0.25$ (solid line), $\Delta \mu \mathrm{x}=$ 0.34 (dotted line), $\Delta \mu \mathrm{x}=0.73$ (dashed line).

agree nicely with those obtained at the Mo-K edge. Additionally, as shown in Table 6, each Se was surrounded by both $S$ and Se neighbors at distances of 3.18 and $3.28 \AA$, respectively.

HD-Se on Com-CoMo/Al $\mathrm{Al}_{2}$ at $473 \mathrm{~K}$. Figure 8a displays the EXAFS data taken at the Se edge of the com-CoMo/Al catalyst after reaction with selenophene/ $\mathrm{H}_{2}$ at $473 \mathrm{~K}$. Figure 

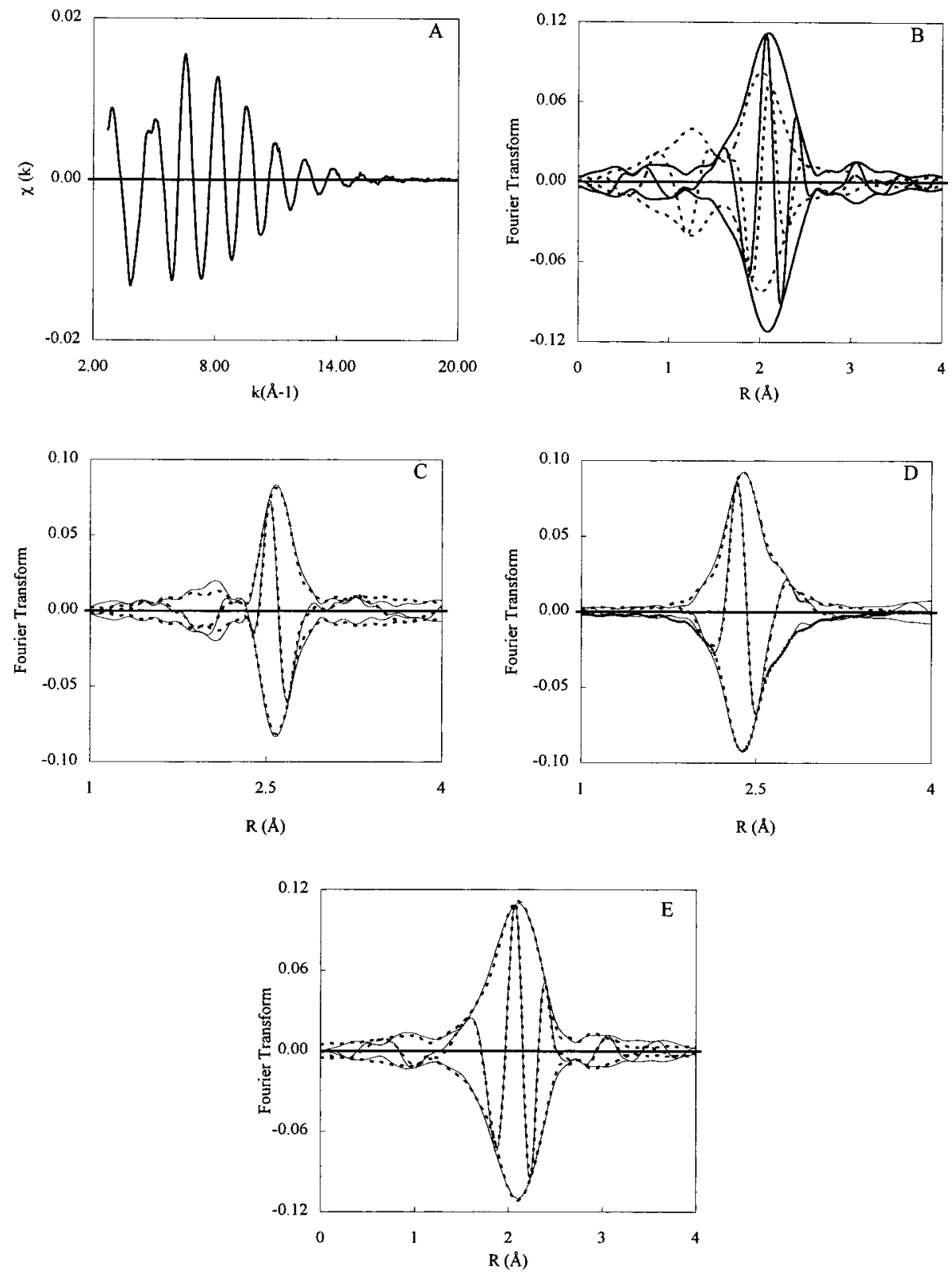

Figure 9. (A) $\mathrm{Se}-\mathrm{K}$ EXAFS spectrum (unweighted) of sulfided com-CoMo/ $\mathrm{Al}_{2} \mathrm{O}_{3}$ after HD-Se at $673 \mathrm{~K}$. (B) Corresponding Fourier transform $\left(k^{1}\right.$, $\left.\Delta k=3.4-14.0 \AA^{-1}\right)$ (solid line) and for comparison of sample after HD-Se at $473 \mathrm{~K}$ (dotted line). (C) Fourier transform $\left(k^{1}, \Delta k=4.0-13.5 \AA^{-1}\right.$, $\mathrm{Se}-$ Mo phase corrected) of $\mathrm{Se}-\mathrm{Mo}$ contribution; difference file: EXAFS spectrum minus calculated $\mathrm{Se}-\mathrm{Co}, \mathrm{Se}-\mathrm{C}, \mathrm{Se}-\mathrm{Se}, \mathrm{Se}-\mathrm{S}$ contributions (solid line) and $\mathrm{Se}-\mathrm{Mo}$ fit (dotted line). (D) Fourier transform $\left(k^{1}, \Delta k=4.0-13.5 \AA^{-1}\right.$, Se-Co phase corrected) of Se-Co contribution; difference file: EXAFS spectrum minus calculated $\mathrm{Se}-\mathrm{Mo}, \mathrm{Se}-\mathrm{Se}, \mathrm{Se}-\mathrm{S}$, Se-C contributions (solid line) and $\mathrm{Se}-\mathrm{Co}$ fit (dotted line). (E) Fourier Transform $\left(k^{1}, \Delta k=2.7-18.0 \AA^{-1}\right)$ of sulfided $\mathrm{Mo} / \mathrm{Al}_{2} \mathrm{O}_{3}$ after $\mathrm{HD}-\mathrm{Se}$ at $673 \mathrm{~K}$ (solid line) and best fit (dotted line).

$8 \mathrm{~b}$ contains the $k^{1}$ weighted Fourier Transform of the EXAFS data together with the best fit. Analysis of the data revealed that the peak at about $1.2 \AA$ is due to a $\mathrm{Se}-\mathrm{C}$ contribution at $1.71 \AA$ (see Table 6). The peak around $2.0 \AA$ is solely due to a $\mathrm{Se}-\mathrm{Co}$ contribution at $2.39 \AA$. On average, each Se atom is coordinated to one Co atom.

To check that the data of HD-Se at $473 \mathrm{~K}$ were not influenced by the duration of the reaction, several samples were characterized after varying reaction times. As shown in Figure 8c, raising the reaction time has almost no effect on the shape and amplitude of the Fourier transforms of the raw data. Nevertheless, the X-ray absorption data showed a clear rise in the absorption step $(\Delta \mu \mathrm{x})$ from 0.25 from to 0.75 . This indicates that, although the amount of $\mathrm{Se}$ incorporated in the catalyst increased with the reaction time, all Se atoms were in a similar local structure. Indeed, data analysis of the spectra showed only small variations of the structural parameters within the limits of accuracy. Only the Debye-Waller factors of all contributions slightly increased with a longer exposition time. Unfortunately, no data could be taken at the Mo and Co edge after reaction at $473 \mathrm{~K}$.

HD-Se on Com-CoMo/ $/ \mathrm{Al}_{2} \mathrm{O}_{3}$ at $673 \mathrm{~K}$. In Figure 9 the data taken at the Se edge are shown after reaction of com-CoMo/ $\mathrm{Al}$ with selenophene at $673 \mathrm{~K}$. For comparison, Figure $9 \mathrm{~b}$ also contains the Fourier transform of the EXAFS data measured after HD-Se at $473 \mathrm{~K}$. It is clear that after reaction at $673 \mathrm{~K}$ the amplitude at around $1.2 \AA$ due to the $\mathrm{Se}-\mathrm{C}$ contribution was strongly reduced as compared to that after reaction at 473 $\mathrm{K}$. The decrease in $\mathrm{Se}-\mathrm{C}$ coordination was also confirmed by data analysis (see Table 6). Additionally, the amplitude between 2.0 and $2.5 \AA$ has increased. The analysis of the data revealed that the increase was due to the presence of an additional backscatterer, namely Mo at a bond distance of $2.55 \AA$. Further, in the analysis of the higher shells relatively small $\mathrm{Se}-\mathrm{S}$ and 

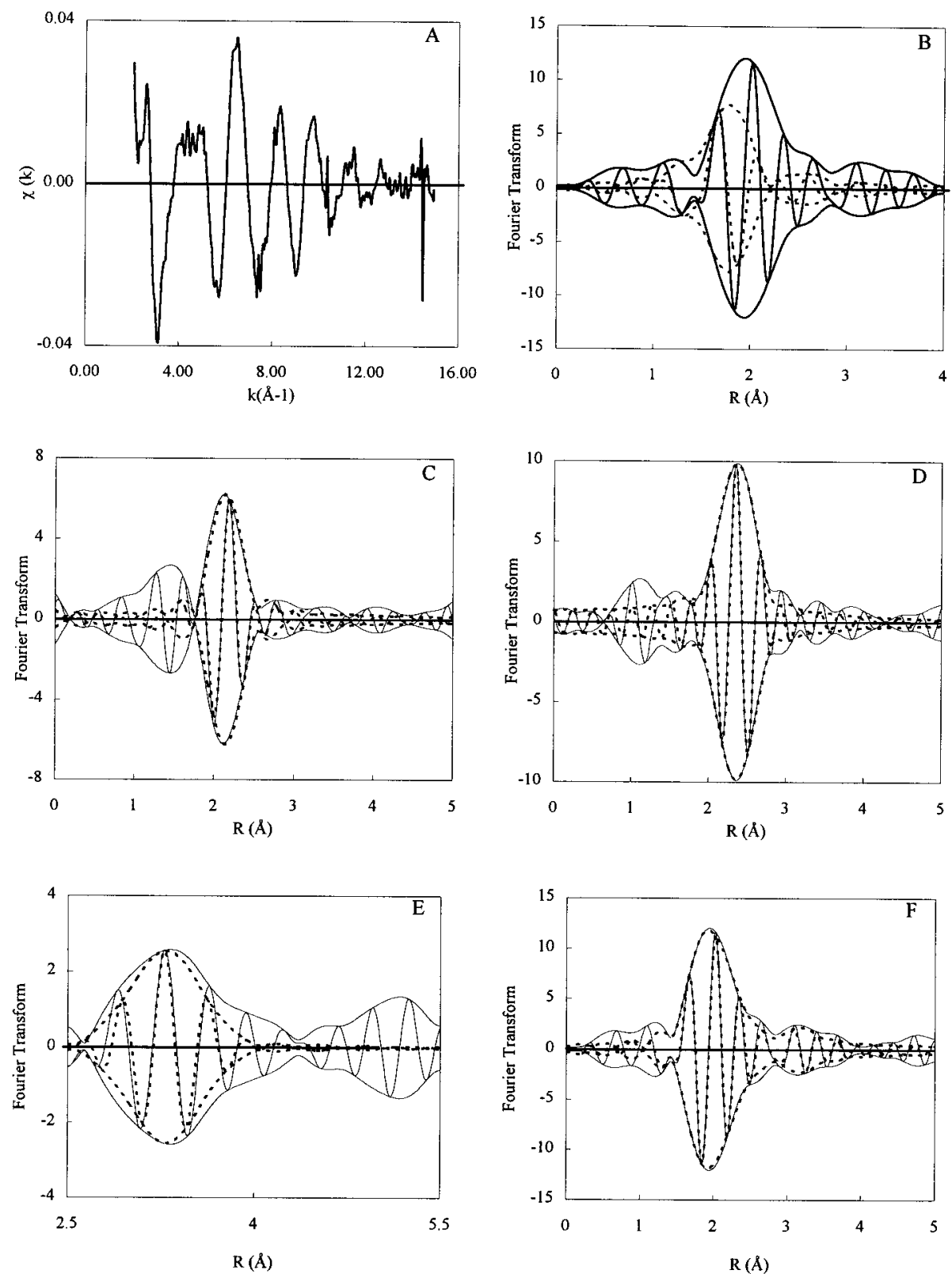

Figure 10. (A) $\mathrm{Co}-\mathrm{K}$ EXAFS spectrum (unweighted) of sulfided com-CoMo/ $\mathrm{Al}_{2} \mathrm{O}_{3}$ after $\mathrm{HD}-\mathrm{Se}$ at $673 \mathrm{~K}$. (B) Corresponding Fourier Transform $\left(k^{3}, \Delta k=3.0-12.0 \AA^{-1}\right)$ (solid line) and for comparison of sulfided sample before HD-Se (dotted line). (C) Fourier transform ( $k^{3}, \Delta k=3.0-12.0$ $\AA^{-1}, \mathrm{Co}-\mathrm{S}$ phase corrected) of $\mathrm{Co}-\mathrm{S}$ contribution; difference file: EXAFS spectrum minus calculated Co-Se and Co-Mo contributions (solid line) and $\mathrm{Se}-\mathrm{Mo}$ fit (dotted line). (D) Fourier transform $\left(k^{3}, \Delta k=3.0-12.0 \AA^{-1}\right.$, Co-Se phase corrected) of Co-Se contribution; difference file: EXAFS spectrum minus calculated $\mathrm{Co}-\mathrm{S}$ and $\mathrm{Co}-$ Mo contributions (solid line) and $\mathrm{Co}-\mathrm{Se}$ fit (dotted line). (E) Fourier transform $\left(k^{3}, \Delta k=\right.$ 3.0-12.0 $\AA^{-1}, \mathrm{Ni}-$ Mo phase corrected) of $\mathrm{Co}-$ Mo contribution; difference file: EXAFS spectrum minus calculated $\mathrm{Co}-\mathrm{S}$ and $\mathrm{Co}-\mathrm{Se}$ contributions (solid line) and $\mathrm{Co}-$ Mo fit (dotted line). (F) Fourier transform $\left(k^{3}, \Delta k=3.0-12.0 \AA^{-1}\right.$ ) of sulfided com-CoMo/ $\mathrm{Al}_{2} \mathrm{O}_{3}$ after $\mathrm{HD}-\mathrm{Se}$ at $673 \mathrm{~K}$ (solid line) and best fit (dotted line).

$\mathrm{Se}-\mathrm{Se}$ contributions were found. The fits of the individual $\mathrm{Se}-$ $\mathrm{Co}$ and $\mathrm{Se}-\mathrm{Mo}$ contributions and the total fit of the experimental data are displayed in Figure 9c-e.

Analysis of the data obtained at the $\mathrm{Mo}-\mathrm{K}$ edge with com$\mathrm{CoMo} / \mathrm{Al}_{2} \mathrm{O}_{3}$ after $\mathrm{HD}-\mathrm{Se}$ at $673 \mathrm{~K}$ gave the same results as the data measured on the unpromoted catalyst (see Table 4). Comparison of the sulfided catalyst (center) with the catalyst after HD-Se (bottom) shows a small growth of the $\mathrm{MoS}_{2}$ slabs $\left(N_{\mathrm{Mo}-\mathrm{Mo}} 2.9\right.$ versus 2.5$)$ and a loss of the $\mathrm{Mo}-\mathrm{O}_{\text {support }}$ contribution. Sulfur ligands were replaced by Se ligands at a bond length of $2.52 \AA$ in nice agreement with the data of the $\mathrm{Se}-\mathrm{K}$ edge (note that the values of the Debye-Waller factors are also comparable). The Mo-Se coordination number of 1.1 was lower than the number found with the unpromoted catalyst, viz. 1.6. However, the Mo-S coordination number of the promoted catalyst was significantly higher, i.e., 5.3 as compared to 4.4 for $\mathrm{Mo} / \mathrm{Al}_{2} \mathrm{O}_{3}$.
Figure 10 displays the data obtained at the $\mathrm{Co}-\mathrm{K}$ edge for com-CoMo/ $/ \mathrm{Al}_{2} \mathrm{O}_{3}$. Comparison of the sulfided catalyst before and after HD-Se (Figure 10b) revealed that the Fourier transform of the Co EXAFS data also drastically changed upon reaction with selenophene. The maximum of the peak due to the first shell shifted to higher $R$ values, together with an increase in its amplitude. Data analysis (see Table 5) showed the incorporation of two Se neighbors at a bond distance of $2.35 \AA$ in agreement with the data from the $\mathrm{Se}-\mathrm{K}$ edge and a simultaneous decrease of the sulfur coordination from 5.2 to 1.8 . In addition to the $\mathrm{Se}-\mathrm{Co}$ and $\mathrm{Co}-\mathrm{Se}$ coordination distances, also the DebyeWaller factors of the $\mathrm{Se}-\mathrm{Co}$ and $\mathrm{Co}-\mathrm{Se}$ contribution were comparable, i.e., 0.00107 and $0.00163 \AA$, ${ }^{2}$ respectively. Further, the Co-Mo distance increased from 2.81 to $3.28 \AA$, which was accompanied by a strong decrease in the DebyeWaller factor. A decreasing Debye-Waller factor was also observed with the $\mathrm{Co}-\mathrm{S}$ contribution. The individual $\mathrm{Co}-\mathrm{S}$, 


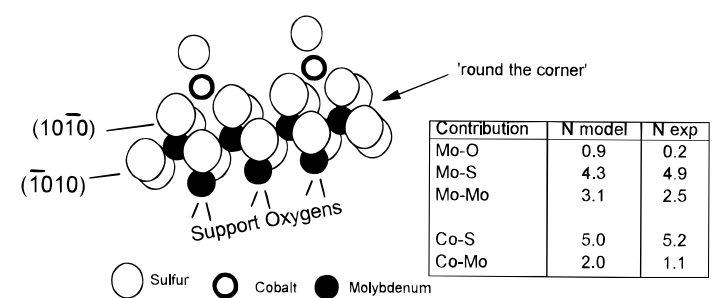

Figure 11. Structure of the CoMo catalysts after sulfidation at $673 \mathrm{~K}$.

$\mathrm{Co}-\mathrm{Se}$, and $\mathrm{Co}-\mathrm{Mo}$ contributions are displayed in Figure 10ce. It is clear that the experimental data can adequately be described by the calculated model.

\section{Discussion}

Structure after Treatment with $\mathbf{H}_{2} \mathbf{S} / \mathbf{H}_{2}$. Figure 11 represents a possible structure of the CoMo sulfide phase after sulfidation at $673 \mathrm{~K}$. As can be seen from the table, the coordination numbers in the modeled structure are in reasonable agreement with those obtained in the model fit of the EXAFS data. The Mo-Mo coordination in the model is somewhat larger (3.1 of the model versus 2.5 of fit), indicating that the molybdenum sulfide slabs in the catalysts contain one or two Mo atoms less than represented in Figure 11. The Mo-O contribution indicates that the slabs are anchored to the support via $\mathrm{Mo}-\mathrm{O}-\mathrm{Al}$ linkages as reported earlier. ${ }^{45}$ In our former study we designated the (1010) plane as a likely candidate for anchoring to the surface of the support since the (exposed) Mo atoms are easily available for formation of $\mathrm{Mo}-\mathrm{O}-\mathrm{Al}$ bonds without steric constraints. However, as outlined by Louwers and Prins ${ }^{46}$ the location of the Co atoms in the promoted catalyst is most likely on the (1010) edges. Placement of the Co atoms on the (1010) edges is only possible after a reconstruction of the edge. For these reasons, Figure 11 depicts the $\mathrm{MoS}_{2}$ slab bonded to the support via the (1010) edge and the location of the Co atoms on the (1010) edge. However, although in such a geometrical structure the bond distances are in perfect agreement with the EXAFS data, the Co-Mo coordination is 2 instead of 1.1 obtained from data analysis. It may therefore be possible that the Co atoms are also present at reconstructed (1010) edges or at an "around the corner" position denoted by the arrow in Figure 11. Since in both configurations stacking of slabs cannot be expected the CoMoS phase can be denoted as type $\mathrm{I} .{ }^{25}$

Treatment with $\mathrm{H}_{2}$ and $\mathrm{H}_{2}$ /Thiophene at $673 \mathrm{~K}$ : Generation of Sulfur Vacancies. First, our results demonstrate that it is possible to characterize sulfided catalysts with EXAFS under reaction conditions at $673 \mathrm{~K}$. Despite this high temperature, the signal-to-noise ratio of the data was still very good, and in addition no anharmonic behavior of the interatomic motions was observed in the analysis of the data. Characterization of $\mathrm{Mo} / \mathrm{Al}_{2} \mathrm{O}_{3}$ (Table 2) during treatment with $\mathrm{H}_{2}$ at $673 \mathrm{~K}$ revealed no significant changes in the $\mathrm{Mo}-\mathrm{S}$ coordination number as compared to the "fully" sulfided catalyst under $\mathrm{H}_{2} \mathrm{~S} /$ $\mathrm{H}_{2}$. At first sight this result seems to disagree with the small particle size of the $\mathrm{MoS}_{2}$ slabs as deduced from the low MoMo coordination number. The value of 2.9 for $N_{\text {Mo-Mo }}$ points to $\mathrm{MoS}_{2}$ slabs containing six or seven Mo atoms as represented in Figure 11. A significant fraction of the Mo atoms is thus situated at edge and corner positions. One may expect that the terminal sulfurs (or bridging $\mathrm{S}_{2}{ }^{2-}$ groups) coordinated to these Mo atoms can easily be hydrogenated, resulting in coordinatively unsaturated Mo sites. However, in the TPR $-\mathrm{S}$ studies of highly loaded $\mathrm{MoS}_{2} / \mathrm{Al}_{2} \mathrm{O}_{3}$ catalysts Moulijn and co-workers ${ }^{47}$ observed a consumption of only $0.1-0.2 \mathrm{~mol} \mathrm{H}_{2} / \mathrm{mol}$ Mo between 273 and $823 \mathrm{~K}$. Further, Kabe et al. ${ }^{48}$ found in their ${ }^{35} \mathrm{~S}$-labeled dibenzothiophene studies that hardly any sulfur was released from the catalyst upon $\mathrm{H}_{2}$ treatment, except when dibenzothiophene was also present in the feed. Due to the high destabilization of the resulting metal sulfide phase upon hydrogenation of sulfur ligands a significant number of reactive sulfur ligands can apparently only be removed when they are immediately replaced by the organosulfur compound.

In agreement with reports from Topsøe et al., ${ }^{29} \mathrm{a}$ clear change was observed in the $\mathrm{Co}-\mathrm{S}$ coordination number (from 6.0 to 5.2) when $\mathrm{CoMo} / \mathrm{Al}_{2} \mathrm{O}_{3}$ was treated with $\mathrm{H}_{2}$. In an optimal catalyst all Co atoms are highly dispersed and located on edges of $\mathrm{MoS}_{2}$ slabs. In that case, all Co atoms will be coordinated to four sulfur atoms of the $\mathrm{MoS}_{2}$ lattice and to one or two terminal sulfur atoms (see Figure 11). ${ }^{25}$ Since the latter sulfur atoms are quite labile they can be easily hydrogenated and removed as $\mathrm{H}_{2} \mathrm{~S}$. This strongly suggests that promotion of Mo catalysts by Co can actually lead to a different type of sulfur vacancy from which sulfur can be removed more easily and thus to a higher number of active sites. Besides, Topsøe and co-workers (see ref 16) have recently shown that the metalsulfur bond strength in a CoMoS structure is much weaker than in bulk Mo or Co sulfide, due to a different average filling of the $d$-band. This indicates that upon promotion with Co not only the number of sites, but also the intrinsic activity of these sites will also be different.

Interestingly, the $\mathrm{Co}-\mathrm{S}$ coordination has not significantly increased upon exposure to thiophene $/ \mathrm{H}_{2}$. In our opinion, this strongly suggests that at these reaction temperatures the ratelimiting step in the HDS mechanism is not $\mathrm{C}-\mathrm{S}$ scission or $\mathrm{H}_{2} \mathrm{~S}$ removal but the adsorption of thiophene on the active sites. As soon as thiophene has been adsorbed on the active site it immediately reacts to butene and $\mathrm{H}_{2} \mathrm{~S}$ leaving the vacant active site as detected by EXAFS. In agreement, most studies on HDS kinetics deal with Langmuir-Hinshelwood-type equations, the adsorption being the rate-determining step at higher temperatures. ${ }^{49}$

Structure of the Active Sites of $\mathrm{Mo} / \mathrm{Al}_{2} \mathrm{O}_{3}$, $\mathrm{HD}-\mathrm{Se}$ at 673 K. To obtain information on the nature and structural surrounding of the active sites on which selenophene adsorbs we used the EXAFS data to develop a structural model for the adsorption (active) site. The data analyses of the spectra obtained at the Se edge of the Mo/Al catalyst after HD-Se (Table 5) show that each Se is coordinated by two or three Mo atoms. This implies that these Se atoms are not likely to be only terminal ligands, for instance, bonded to the exposed Mo atoms on the (1010) edges. In that case, a $\mathrm{Se}-\mathrm{Mo}$ coordination number of about 1.0 would be expected. The measured coordination number of 2.4 points to incorporation of the $\mathrm{Se}$ atom in bridging sulfur positions on the (1010) $(\mathrm{Se}-\mathrm{Mo}$ coordination of 2) and (1010) edges (Se-Mo coordination of 3) of the $\mathrm{MoS}_{2}$ slabs. The nearby presence of $\mathrm{S}$ and $\mathrm{Se}$ neighbors at bond distances of 3.18 and 3.28/4.09 A, respectively, agrees with such a location on the edges. Figure 12a exhibits a possible structure of $\mathrm{MoS}_{2}$ with Se atoms on the edges. As can be seen from the accompanying table the model structure agrees with the structural parameters as determined with EXAFS.

The results clearly show that in agreement with the current general opinion the active HDS sites in the unpromoted catalyst at a reaction temperature of $673 \mathrm{~K}$ are sulfur vacancies created by removal of bridging sulfur atoms at the edges of the $\mathrm{MoS}_{2}$ slabs. Apparently, both (1010) and (1010) edges are involved, which means that not all (1010) edges are catalytically inactive (due to bonding to the surface of the support) in agreement with the loss of the $\mathrm{Mo}-\mathrm{O}_{\text {support }}$ contribution. 
A

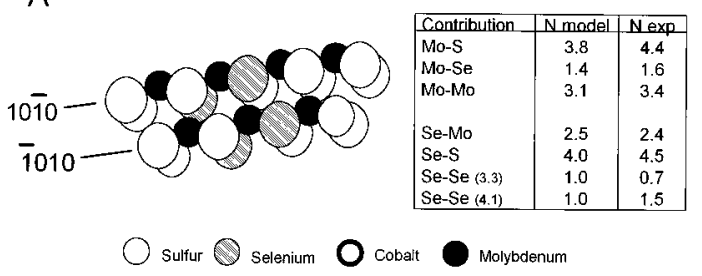

$B$

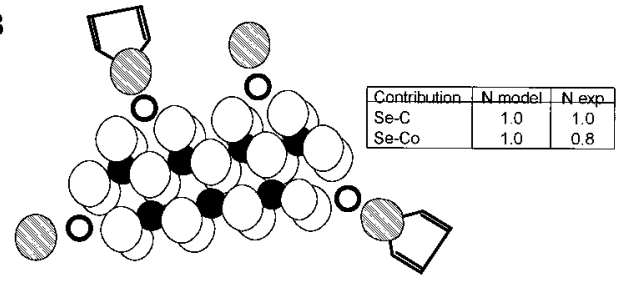

C

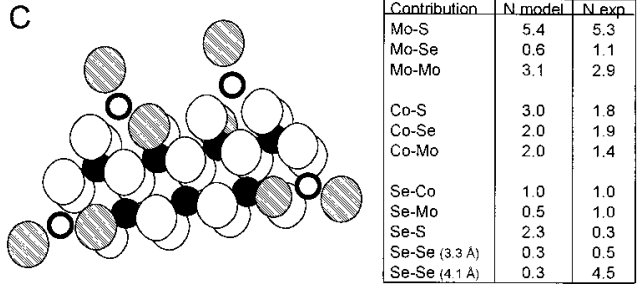

Figure 12. Structure of the CoMo catalysts after reaction with selenophene (A) unpromoted $\mathrm{Mo} / \mathrm{Al}_{2} \mathrm{O}_{3}$ catalyst after HD-Se at 673 $\mathrm{K}$, (B) $\mathrm{CoMo} / \mathrm{Al}_{2} \mathrm{O}_{3}$ catalyst after $\mathrm{HD}-\mathrm{Se}$ at $473 \mathrm{~K}$, and (C) $\mathrm{CoMo} /$ $\mathrm{Al}_{2} \mathrm{O}_{3}$ catalyst after $\mathrm{HD}-\mathrm{Se}$ at $673 \mathrm{~K}$.

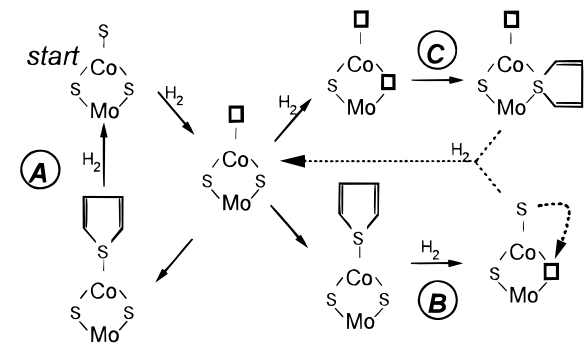

Figure 13. Possible reaction schemes for the hydrodesulfurization of thiophene over Co-promoted Mo sulfide catalysts.

Structure of Active Sites of Com-CoMo/ $/ \mathrm{Al}_{2} \mathrm{O}_{3}$, HD-Se at $473 \mathrm{~K}$. The characterization of the com-CoMo/Al catalyst after $\mathrm{HD}-\mathrm{Se}$ at $473 \mathrm{~K}$ reveals that $\mathrm{Se}$ is coordinated to Co with a $\mathrm{Se}-\mathrm{Co}$ coordination number of 1.0. The most likely position of the Se atoms is therefore as a terminal ligand on the Co atoms located on the edges of the $\mathrm{MoS}_{2}$ slabs. Since Se in selenophene is bonded to two carbon atoms, the value of the $\mathrm{Se}-\mathrm{C}$ coordination number of 1.0 (which does not change with the duration of the reaction) suggests that about half of the Se atoms are bonded to the hydrocarbon ring as depicted in Figure 12b. Another possibility is that opening of the selenophene ring has already proceeded and that all Se atoms are linked to the remaining butene chain. The observation of a $\mathrm{Se}-\mathrm{S}$ bond distance of $2.89 \AA$ might be due to the coordination to the $S$ atom between the Mo and Co atoms at the edges of the $\mathrm{MoS}_{2}$ slabs or to a second terminal ligand on the Co.

The above results demonstrate that the active HDS site at $473 \mathrm{~K}$ can be formally identified as a terminal sulfur vacancy at the Co atom in the "Co-Mo-S" structure. Selenophene is chemisorbed on $\mathrm{Co}$, subsequently hydrogenated, and released as $\mathrm{H}_{2} \mathrm{Se}$ (route $\mathrm{A}$ in Figure 13). As mentioned above, the intrinsic activity of Co might well be enhanced by promotion by Mo through changes in the filling of the $d$-band and the metal-sulfur bond strength. ${ }^{50-52}$

The observation with EXAFS of a $\mathrm{Se}-\mathrm{C}$ coordination, furthermore, implies that the scission of the $\mathrm{Se}-\mathrm{C}$ bond at 473
$\mathrm{K}$ is a slow step as compared to the generation of sulfur vacancies and subsequent adsorption of thiophene. If the hydrogenolysis of the $\mathrm{C}-\mathrm{S}$ bond would be fast, the "lifetime" of the state as shown in Figure $12 \mathrm{~b}$ would be very short and the $\mathrm{Se}-\mathrm{C}$ contribution would be beyond detection with EXAFS.

Our results clearly show that the reaction of sulfided catalysts with selenophene can be followed with EXAFS, which seems to disagree with the earlier report by Medici et al. ${ }^{28}$ However, these authors carried the reaction out at room temperature at which sulfur vacancies are not likely to be formed. At such a low temperature only physisorption or possibly chemisorption can take the place of selenophene on sulfur atoms, which, as already discussed by the authors, cannot be seen with EXAFS. The disagreement between the study of Medicie et al. and the findings of Startsev et al. ${ }^{26}$ (also obtained at room temperature) therefore still remains unless the latter catalysts were pretreated, for example, with hydrogen, although this was not mentioned.

Structure of Active Sites of Com-CoMo/Al $\mathrm{Al}_{2} \mathrm{O}_{3}, \mathrm{HD}-\mathrm{Se}$ at 673 K. Two striking differences can be observed when comparing the EXAFS data obtained at 473 and $673 \mathrm{~K}$. First, both Co and Mo neighbors are present in the coordination shell of the $\mathrm{Se}$ atoms. Second, the $\mathrm{Se}-\mathrm{C}$ coordination is no longer detectable.

The Co-Mo coordination number of 1.4 indicates that some Co atoms are 2-fold coordinated to Mo atoms and are located on the (1010) plane as exhibited in Figure 12c. This type of CoMoS phase, which is no longer bonded to the support, can be considered as CoMoS type II. It might be possible that stacking of the $\mathrm{MoS}_{2}$ slabs has proceeded, but EXAFS does not contain any information on stacking. The $\mathrm{Se}-\mathrm{Co}$ and $\mathrm{Se}-$ Mo coordination numbers of 1.0, furthermore, imply that each Se has both Co and Mo neighbors. This means that most of the Se atoms have to be located in the bridging sulfur positions between $\mathrm{Co}$ and Mo. The increase in the $\mathrm{Co}-\mathrm{Mo}$ distance from 2.81 to $3.28 \AA$ also agrees with such a bridging position in which sulfur atoms are replaced by the larger selenium atoms. Figure $12 \mathrm{c}$ represents a possible structural model in which the Se atoms are placed at both the terminal positions of the Co and in the edges of the $\mathrm{MoS}_{2}$ slabs (corner positions might also be considered). As can be seen, however, the $\mathrm{Se}-\mathrm{S}$ and $\mathrm{Se}-\mathrm{Se}$ coordination numbers of 0.3 and $0.5 / 4.5$, respectively, do not agree with the proposed model. Comparison of the unpromoted with the promoted catalyst (Table 6) also reveals large changes in the Debye-Waller factors and inner potentials of the $\mathrm{Se}-\mathrm{S}$ and $\mathrm{Se}-\mathrm{Se}$ contribution. Unfortunately, attempts to get more comprehensive results on this point failed. Although several models are thus possible (e.g., as the one in Figure 12c), the agreement between the Mo and Co data provides sufficiently convincing information that the $\mathrm{Se}$ atoms are located in the position of bridging sulfur atoms on the edges of the $\mathrm{MoS}_{2}$ slabs.

For the incorporation of Se atoms in the position of bridging sulfur atoms at the $\mathrm{MoS}_{2}$ edges essentially three routes can be considered. First, selenophene can initially adsorb on the terminal position on the Co atom and subsequently spill over to the "edge" position (route B in Figure 13). This spillover must be enabled by removal of the bridging $\mathrm{S}$ on the $\mathrm{MoS}_{2}$ edges. A second possibility is that no spillover occurs but a direct $\mathrm{Se}-\mathrm{S}$ exchange (not depicted). The temperature of 673 $\mathrm{K}$ should be high enough to make such an exchange kinetically possible. In addition, $\mathrm{MoSe}_{2}$ is thermodynamically more stable than $\mathrm{MoS}_{2}$, which provides a driving force for such an exchange. Third, a bridging vacancy on the edge can be initially formed on which selenophene can directly adsorb (route C in Figure 13). Our EXAFS data do not contain sufficient information to discriminate between these three routes. In a subsequent paper thiophene conversion experiments will be presented that in our 
opinion support route $\mathrm{C}$. This means that next to the terminal sulfur vacancy on Co a new type of active site may be formed at $673 \mathrm{~K}$ that consists of a sulfur vacancy between the Co and Mo atoms. As a result, the reaction mechanisms currently proposed by Topsøe et al. ${ }^{53}$ and Startsev, ${ }^{54}$ that both describe the reaction occurring only in the coordination sphere of $\mathrm{Co}$ (route A in Figure 13), might have to be extended. In any case, our results demonstrate that at $673 \mathrm{~K}$ also the sulfurs coordinated to both Co and Mo atoms might play an important role in the reaction mechanism.

Finally, the absence of the $\mathrm{Se}-\mathrm{C}$ coordination at $673 \mathrm{~K}$ indicates that the $\mathrm{C}-\mathrm{Se}$ scission is no longer slow as compared to the generation of vacancy or to the adsorption of a reactant on this vacancy. As soon as the selenophene is adsorbed hydrogenolysis of the $\mathrm{C}-\mathrm{Se}$ bonds takes place and the "adsorbed" state is undetectable with EXAFS. These results agree with the EXAFS results of the adsorption experiments of thiophene on $\mathrm{Mo} / \mathrm{Al}_{2} \mathrm{O}_{3}$, which suggest that the adsorption of thiophene is the rate-limiting step in HDS at $673 \mathrm{~K}$.

\section{Conclusions}

In this study detailed information concerning the behavior of sulfur (as represented by $\mathrm{Se}$ ) in a $(\mathrm{Co}) \mathrm{Mo} / \mathrm{Al}_{2} \mathrm{O}_{3}$ hydrotreating catalyst has been obtained.

1. Characterization in situ of the "Co-Mo-S" structure at $673 \mathrm{~K}$ in a flow of $\mathrm{H}_{2}$ shows that on Co sulfur vacancies are easily formed. In contrast, no detectable change in sulfur coordination of the Mo atoms is observed.

2. Reaction of the thiophene analogue selenophene at 673 $\mathrm{K}$ with a $\mathrm{Mo} / \mathrm{Al}_{2} \mathrm{O}_{3}$ catalyst leads to incorporation of the $\mathrm{Se}$ atoms at bridging sulfur positions on the edges of the $\mathrm{MoS}_{2}$ slabs.

3. At $473 \mathrm{~K}$ reaction of selenophene with the promoted catalyst only leads to adsorption of Se and subsequent removal as $\mathrm{H}_{2} \mathrm{Se}$ on the terminal position on the Co atoms.

4. Characterization of $\mathrm{CoMo} / \mathrm{Al}_{2} \mathrm{O}_{3}$ catalyst after $\mathrm{HD}-\mathrm{Se}$ at $673 \mathrm{~K}$ also shows that $\mathrm{Se}$ is in a bridging position at the $\mathrm{MoS}_{2}$ edges between Co and Mo. Exchange of S for Se or spillover of $\mathrm{Se}$ is proposed from the terminal adsorption site on Co to this bridging position. However, adsorption of the reactant on a sulfur vacancy in this bridging location is also possible and in line with the conversion experiments described a following paper. ${ }^{30}$

5. An EXAFS study (Mo, Co, and Se edges) of the adsorption of selenophene under reaction conditions allows one to investigate the behavior of the sulfur from the reacting species on the surface of metal sulfide catalysts.

Acknowledgment. We gratefully acknowledge the financial support of Akzo-Nobel for construction of the in situ equipment and Ad van der Eerden and the Daresbury station managers Gert van Dorssen and Fred Mosselmans for their support and help with the measurements.

\section{References and Notes}

(1) Massoth, F. E. Adv. Catal. 1978, 27, 265.

(2) Gates, B. C.; Katzer, J. R.; Schuit, G. C. A. Chemistry of Catalytic Processes; McGraw-Hill: New York, 1979.

(3) Ratnasamy, P.; Sivasanker, S. Catal. Rev.-Sci. Eng. 1980, 22, 401.

(4) Grange, P. Catal. Rev. Sci. Eng. 1980, 21, 135.

(5) Keely, W. M.; Jerus, P.; Dienes, E. K.; Hausberger, A. L. Catal. Rev.-Sci. Eng. 1984, 26, 485.
(6) Dellanay, F. Appl. Catal. 1985, 16, 135

(7) Topsøe, H.; Clausen, B. S.; Topsøe, N. Y.; Pedersen, E. Ind. Eng. Chem. Fundam. 1986, 25, 25.

(8) Topsøe, H.; Clausen, B. S. App. Catal. 1986, 25, 273.

(9) Prins, R.; de Beer, V. H. J.; Somorjai, G. A. Catal. Rev.-Sci. Eng. 1989, 31,1 .

(10) Luck, F. Bull. Soc. Chim. Belg. 1991, 100, 781

(11) Breysse, M.; Portefaix, J. L.; Vrinat, M. Catal. Today 1991, 10, 489.

(12) Delmon, B. Catal. Lett. 1993, 22, 1. 177.

(14) Startsev, A. N. Catal. Rev.-Sci. Eng. 1995, 37, 353.

(15) Delmon, B. Bull. Soc. Chim. Belg. 1995, 104, 173.

(16) Topsøe, H.; Clausen, B. S.; Massoth, F. E. Catal.-Sci. Technol. 1996, 11 .

(17) Schuit, G. C. A.; Gates, B. C. AIChE J. 1973, 19, 417.

(18) Voorhoeve, R. J. H.; Stuiver, J. C. M. J. Catal. 1971, 23, 243.

(19) Farragher, A. L.; Cossee, P. Proc. 5th ICC; Hightower, J. W., Ed.

1973, 1301.

(20) Hagenbach, G.; Courty, P.; Delmon, B. J. Catal. 1971, 23, 295.

(21) Crajé, M. W. J.; de Beer, V. H. J.; van der Kraan, A. M. Bull. Soc. Chim. Belg. 1991, 100, 953.

(22) Crajé, M. W. J.; de Beer, V. H. J.; van der Kraan, A. M. Appl. Catal. 1991, 70, L7.

(23) Bouwens, S. M. A. M.; Prins, R.; de Beer, V. H. J.; Koningsberger, D. C. J. Phys. Chem. 1990, 94, 3711.

(24) Bouwens, S. M. A. M.; van Veen, J. A. R.; Koningsberger, D. C.; de Beer, V. H. J.; Prins, R. J. Phys. Chem. 1991, 95, 123.

(25) Bouwens, S. M. A. M.; van Zon, F. B. M.; van Dijk, M. P.; van der Kraan, A. M.; de Beer, V. H. J.; van Veen, J. A. R.; Koningsberger, D. C. J. Phys. Chem. 1994, 146, 375.

(26) Startsev, A. N.; Shkuropat, S. A.; Kriventsov, V. V.; Kochubey, D. I.; Zamaraev, K. I. Mendeleev Commun. 1991, 1, 6.

(27) Ledoux, M. J.; Segura, Y.; Panissod, P. Prepr. Div. Petrol. Chem.

1990, 35, 217.

(28) Medici, L.; Harada, M.; Prins, R. Mendeleev Commun. 1996, 121.

(29) Topsøe, H.; Clausen, B. S.; Topsøe, N. Y.; Nørskov, J. K.; Ovesen,

C. V.; Jacobsen, C. J. H. Bull. Soc. Chim. Belg. 1995, 104, 283.

(30) Leliveld, R. G.; van Dillen, A. J.; Geus, J. W.; Koningsberger, D.

C. Submitted to J. Catal.

(31) Vaarkamp, M.; Mojet, B. L.; Kappers, M. J.; Miller, J. T.; Koningsberger, D. C. J. Phys. Chem. 1995, 99, 16067.

(32) Van Zon, J. B. A. D.; Koningsberger, D. C.; Van Blik, H. F. J.; Sayers, D. E. J. Chem. Phys. 1985, 82, 5742.

(33) Matsumoto, K.; Kobayashi, A.; Sasaki, Y. Bull. Chem. Soc. Jpn. 1975, 48, 1009 .

(34) Dickinson, R. G.; Pauling, L. J. Am. Chem. Soc. 1923, 45, 1466.

(35) Elliot, N. J. J. Phys. Chem. 1960, 33, 903.

(36) Nat. Bur. Standards Crit. 1959, 9, 28.

(37) Søtofte, I. Acta Chem. Scand. 1976, A30, 157.

(38) Mustre de Leon, J.; Rehr, J. J.; Zabinsky, S. I. Phys. Rev. B 1991, $44,4146$.

(39) Duivenoorden, F. B. M.; Koningsberger, D. C.; Uh, Y. S.; Gates, B. C. J. Am. Chem. Soc. 1986, 108, 6524.

(40) Kampers, F. W. H.; Engelen, C. W. R.; Van Hooff, J. H. C.; Koningsberger, D. C. J. Phys. Chem. 1990, 94, 8574.

(41) Vaarkamp, M.; Linders, J. C.; Koningsberger, D. C. Physica B 1995, $208 \& 209,159$.

(42) Lytle, F. W.; Sayers, D. E.; Stern, E. A. Physica B 1988, 158, 701.

(43) Stern, E.; Newville, M.; Ravel, B.; Yacoby, Y.; Haskel, D. Physica

$B$ 1995, 208 \& 209, 117.

(44) Li, G. G.; Bridges, F.; Booth, C. H. Phys. Rev. B. 1995, 52, 6332.

(45) Leliveld, R. G.; van Dillen, A. J.; Geus, J. W.; Koningsberger, D.

C. J. Catal. 1997, 165, 184.

(46) Louwers, S. P. A.; Prins, R. J. Catal. 1992, 133, 94.

(47) Scheffer, B.; Dekker, N. J. J.; Mangus, P. J.; Moulijn, J. A. J. Catal.

1990, 121,31

(48) Kabe, T.; Qian, W.; Ishihara, A. J. Phys. Chem. 1994, 98, 912

(49) Vrinat, M. L. Appl. Catal. 1983, 6, 137.

(50) Harris, S.; Chianelli, R. R. J. Catal. 1986, 98, 17.

(51) Topsøe, H.; Clausen, B. S.; Topsøe, N.-Y.; Hyldtoft, J.; Nørskov,

J. K. ACS, Petr. Div. Prepr. 1993, 38, 638.

(52) Ledoux, M. J.; Michaux, O.; Agostini, G.; Panissod, P. J. Catal. 1986, 102,275 .

(53) Topsøe, H.; Clausen, B. S.; Topsøe, N.-Y.; Nørskov, J. K.; Ovesen, C. V.; Jacobsen, C. J. H. Bull. Soc. Chim. Belg. 1995, 104, 283.

(54) Startsev, A. N. Kinet. Catal. 1995, 36, 515. 